\title{
Rare earth elements and Nd isotopes as tracers of modern ocean circulation in the central Mediterranean Sea
}

\author{
Ester Garcia-Solsona ${ }^{\mathrm{a}, *}$, Leopoldo D. Pena ${ }^{\mathrm{a}}$, Eduardo Paredes ${ }^{\mathrm{a}}$, José N. Pérez-Asensio ${ }^{\mathrm{a}, 1}$, \\ Lucía Quirós-Collazos ${ }^{\mathrm{b}}$, Fabrizio Lirer ${ }^{\mathrm{c}}$, Isabel Cacho ${ }^{\mathrm{a}}$ \\ ${ }^{a}$ GRC Geociències Marines, Departament de Dinàmica de la Terra i de l'Oceà, Facultat de Ciències de la Terra, Universitat de Barcelona, Carrer Martí i Franquès s/n, \\ 08028 Barcelona, Spain \\ ${ }^{\mathrm{b}}$ Dep. Biologia Marina i Oceanografia, Institut de Ciències del Mar, CSIC, Pg. Marítim de la Barceloneta, 37-49, 08003 Barcelona, Spain \\ ${ }^{\mathrm{c}}$ Istituto di Scienze Marine (ISMAR)-CNR - Sede di Napoli, Calata Porta di Massa, interno Porto di Napoli 80133, Napoli, Italy
}

\begin{abstract}
A B S T R A C T
Seawater rare earth element (REE) concentrations and Nd isotopic composition $\left(\varepsilon_{\mathrm{Nd}}\right)$ are increasingly applied as valuable tracers of oceanographic processes such as water mass mixing and lithogenic inputs to seawater. However, their measurements are basically lacking in the Mediterranean Sea water column. This study analyzes 9 seawater stations around the central Mediterranean Sea to clarify the relative importance of external sources, vertical (biogeochemical) processes and lateral water mass transport in controlling REE and $\varepsilon_{\mathrm{Nd}}$ distributions. Concentrations of REE do not show nutrient-like profiles with depth, likely indicative of relatively young waters with limited accumulation of remineralized REE. Light REE (LREE) present a non-conservative behavior, which largely peak at surface waters and rapidly decrease with depth. The negative correlation of surface LREE enrichment with offshore distance highlights the influence of continental input from the western Italian coast to the Tyrrhenian surface waters. In contrast to other regions with reported boundary exchange, this process does not modify the $\varepsilon_{\mathrm{Nd}}$ values here. On the other side, distributions of dissolved heavy REE (HREE) and $\varepsilon_{\mathrm{Nd}}$ display a conservative behavior that can be explained by mixing of western- (MAW and WMDW) and eastern- (LIW and EMDW) originated waters. We test this hypothesis with an Optimum Multi-Parameter Analysis (OMPA) including HREE and $\varepsilon_{\mathrm{Nd}}$ parameters. Even though the limited data set, consistent results of water mass fractions are obtained for the four main water masses although with some particularities. While LIW takes on major importance when considering HREE in the model, EMDW fractions are preferentially detected with $\varepsilon_{\mathrm{Nd}}$. This latter finding implies a noticeable deep water flux across the Sicily Strait into the Western Mediterranean that was not clearly evidenced before.
\end{abstract}

\section{Introduction}

Geochemical approaches to trace Mediterranean Sea (MS) water masses, their paths and properties are critical to characterize Mediterranean thermohaline circulation and become a powerful tool to understand the sensitivity of this system to modern and past climatic changes. The central MS (here including the Tyrrhenian Sea, Sicily Strait and Western Ionian Sea) is considered to play an essential role in the dynamics of the MS circulation because it's the place where the main water masses from western and eastern basin origin converge and intense mixing processes take place (Astraldi et al., 2002; Fuda et al., 2002; Falco et al., 2016). Indeed, the region is characterized by significant dynamical processes covering the full spectrum of temporal and spatial scales (Sorgente et al., 2003). However, it remains poorly understood in respect to many of its physical, chemical and biological features. The present study aims at shedding light on these aspects by describing for the first time the seawater distribution of dissolved Rare Earth Elements (REE) and Nd isotopes in the central MS.

\subsection{Hydrography of the central Mediterranean Sea}

Low salinity Atlantic Water (AW) enters the Mediterranean through the Strait of Gibraltar forming meanders towards the east gradually while increasing its salt content (Millot, 1985) and forming the socalled Modified Atlantic Water (MAW). In the central Mediterranean, the MAW splits in two veins, one flowing through the Strait of Sicily into the eastern Mediterranean and the other entering the Tyrrhenian Sea (TYS; Fig. 1), occupying the entire surface layer of the TYS from the surface to $200 \mathrm{~m}$ depth (Millot, 1999; Millot and Taupier-Letage, 2005). The underlying intermediate layer, usually found between 200 and $700 \mathrm{~m}$ depth, is composed of Levantine Intermediate Water (LIW). It originates in the eastern Mediterranean as a result of intense watercooling and evaporation processes that confer it a characteristic salinity maximum. LIW enters the western basin through the shallow sills of the Sicily Strait and is then deviated towards the northeast (Millot and Taupier-Letage, 2005). Both surface and intermediate currents in the TYS follow basically a cyclonic circulation pattern along the Sicilian

\footnotetext{
* Corresponding author. Tel.: + 34934021369.

E-mail address: e.garcia@ub.edu (E. Garcia-Solsona).

${ }^{1}$ Current address: Centre Européen de Recherche et d'Enseignement des Géosciences de l'Environnement (CEREGE - Climate), Aix-en-Provence.
} 

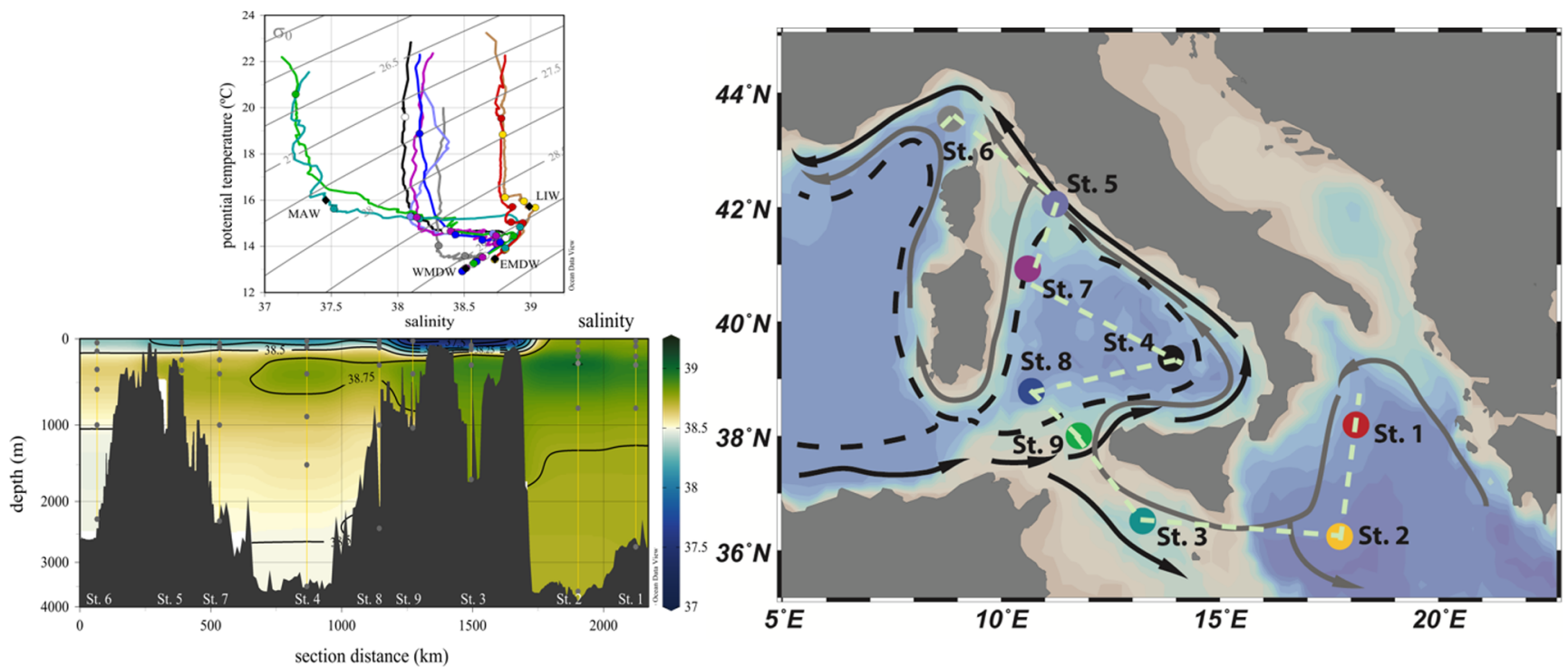

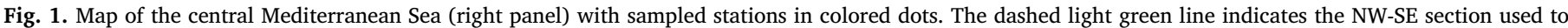

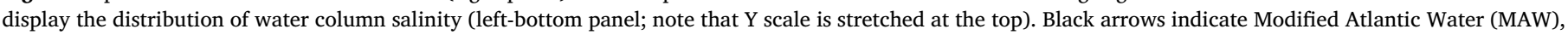

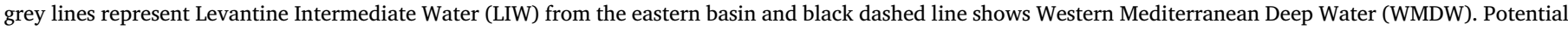

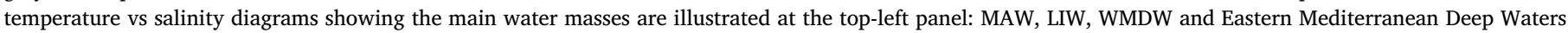
(EMDW). Black diamonds specify the location of water type end-members.

and Italian shelves (Astraldi and Gasparini, 1994) although small but quasi-permanent gyres are also present (e.g. Bonifacio gyre; Vetrano et al., 2010; Iacono et al., 2013). A denser and less salty water mass called Western Mediterranean Deep Water (WMDW) is present between $700 \mathrm{~m}$ down to bottom waters (Serravall and Cristofalo, 1999). It is formed in the Gulf of Lion and feeds the TYS through the Sardinia Channel (Millot, 1999). Produced in the southern Adriatic and filling the eastern basin from about $700 \mathrm{~m}$ to the bottom, the Eastern Mediterranean Deep Water (EMDW) is present along the Ionian western boundary. The upper portion may be considered as transitional EMDW and is thought to cross the Sicily Strait sills to reach the western basin (Sparnocchia et al., 1999; Astraldi et al., 2001) although this has not been clearly established in the literature (Robinson et al., 2001). In the Tyrrhenian basin, another deep water mass termed Tyrrhenian Deep Water (TDW) is defined to be a mixing product of the WMDW and the LIW above it (Rhein et al., 1999) flowing out from the TYS basin (at 700-1000 m) through the Sardinia-Sicily section above the WMDW. However, the processes responsible of the formation of this TDW and the actual water masses involved are still subject of debate (Astraldi and Gasparini, 1994; Millot, 2009, Vetrano et al. 2010; Falco et al., 2016).

\subsection{Systematics of Rare Earth elements and Nd isotopes in seawater}

Rare Earth Elements (REE) are a group of 14 particle reactive chemical elements (from Lanthanum $\mathrm{Z}=57$ to Lutetium $\mathrm{Z}=71$ ) with similar chemical properties and mostly found in the $3+$ oxidation state. Their relative distribution in seawater is sensitive to oceanic processes such as lateral advection of water masses and the effects of biogeochemical cycling like particle scavenging or remineralization (Elderfield, 1988; Sholkovitz et al., 1994; Hathorne et al., 2015; Zheng et al., 2016). Continent-ocean interface processes can also be important sources or sinks of REE to seawater (Jeandel et al., 2011). REE concentrations are generally normalized using Post Archean Australian Sedimentary rock (PAAS; Taylor and McLennan, 1985) to approximate the composition of the continental crust. When doing so, REE dissolved in seawater are characterized by a relative enrichment of the heavy REE (HREE: from Tb to Lu) compared to the light REE (LREE: from La to Gd; e.g. Bertram and Elderfield, 1993). This is attributed to the lanthanide contraction (Zhang and Nozaki, 1996) and the HREE building more stable carbonate complexes in seawater (Byrne and Kim, 1990). As a result of having a higher free metal ion concentration in seawater, the LREE are more particle reactive and are preferentially removed by scavenging processes (Sholkovitz et al., 1994). Another characteristic feature of the oceanic dissolved REE pattern is the oxidative removal of Ce due to formation of insoluble $\mathrm{Ce}^{4+}$. It can be quantified by the "Ce anomaly", which represents the ratio between the measured dissolved Ce concentration and the predicted Ce concentration that would occur without this oxidative removal process (here calculated by interpolating between normalized Pr and Nd neighbors; Garcia-Solsona et al., 2014). Negative Ce anomalies are indicated by values smaller than 1, the smaller the value, the stronger the negative anomaly.

The particular use of Nd isotopic composition as a water mass tracer in oceanographic and paleoceanographic studies (Rickli et al., 2009; Piotrowski et al., 2012; Martin et al., 2012; Stichel et al., 2012) is possible because of its quasi-conservative behavior within distinct intermediate and deep water masses far from continental margins and the absent biological fractionation of Nd isotopes (Frank, 2002; Goldstein and Hemming, 2003). Nd isotopic variations are expressed in epsilon notation as $\varepsilon_{\mathrm{Nd}}=\left(\left[\left({ }^{143} \mathrm{Nd} /{ }^{144} \mathrm{Nd}\right)_{\text {sample }} /\left({ }^{143} \mathrm{Nd} /{ }^{144} \mathrm{Nd}\right)_{\mathrm{CHUR}}\right]-1\right) * 10000$, where CHUR stands for the Chrondritic Uniform Reservoir and represents a present-day average Earth value: $\left({ }^{143} \mathrm{Nd} /{ }^{144} \mathrm{Nd}\right)_{\mathrm{CHUR}}=0.512638$; Jacobsen and Wasserburg, 1980).

\subsection{Objectives of the study}

The goal of the present study is to document, for the first time, the distribution of dissolved REE and $\mathrm{Nd}$ isotopes in the Central Mediterranean sea. Previous data on these geochemical tracers has been published for only few stations in the eastern MS basin $\left(\varepsilon_{\mathrm{Nd}}\right.$ : Tachikawa et al., 2004; Vance et al., 2004) and the western basin (REE: Greaves et al., 1991; unfiltered $\varepsilon_{\mathrm{Nd}}$ : Henry et al., 1994; $\varepsilon_{\mathrm{Nd}}$ and REE: Tachikawa et al., 2004; Garcia-Solsona and Jeandel, 2020). Both REE and Nd isotopes have been applied as geochemical tracers in the marine environment of a variety of processes such as water mass mixing, lithogenic supplies, particle-seawater interactions and modern and past ocean circulation (Elderfield, 1988; Tachikawa et al., 2003; Grenier 
et al., 2018). Indeed, Nd isotopic composition recorded by authigenic and biogenic fractions have been successfully used to trace the past Mediterranean circulation (Cornuault et al., 2018; Dubois-Dauphin et al., 2017; Jiménez-Espejo et al., 2015; Osborne et al., 2008, 2010; Scrivner et al., 2004). Improving the understanding of the MS biogeochemical cycling of these selected trace elements and isotopes is a key issue to better comprehend the processes affecting dissolved constituents in the water column. Processes such as scavenging onto suspended particles, remobilization or redox-induced reactions do exert an essential role in seawater biogeochemistry.

The specific aims of this research are to i) test the applicability of dissolved REE and neodymium isotopes $\left(\varepsilon_{\mathrm{Nd}}\right)$ as conservative water mass mixing tracers in the present day Mediterranean Sea, and ii) detect external lithogenic influences in the central MS from the Western Ionian Sea, Strait of Sicily and Tyrrhenian Sea. From the limited data existing in other parts of the MS, it is clearly not solved whether dissolved REE concentrations and $\varepsilon_{\mathrm{Nd}}$ values in the water column are predominantly reflecting advective transport, external inputs or both (Greaves et al., 1991; Henry et al., 1994; Tachikawa et al., 2004; Ayache et al., 2016; Garcia-Solsona and Jeandel, 2020). In addition, water mass exchange between the eastern and western basins through the Sicily Strait remain still under debate, in particular, concerning deep waters (Robinson et al., 2001). On the other hand, it is known that land-to-ocean transfer of material controls significantly the chemical composition of seawater and the global element cycles. Being a semi-enclosed basin sets the MS with a continent-to-ocean contact ratio two orders of magnitude higher than open oceanic regions (e.g., coastal length versus seawater volume of $3 \cdot 10^{-4} \mathrm{~km} \cdot \mathrm{km}^{-3}$ for the Atlantic and $1 \cdot 10^{-2} \mathrm{~km} \cdot \mathrm{km}^{-3}$ for the MS; The World Factbook 2016-2017; de Walle et al., 1993). In this regard, REE and $\mathrm{Nd}$ isotopes can be significant tools to detect and characterize relevant external lithogenic inputs in the central MS. This kind of approach has already underlined the importance of taking into account continental margins as a source of elements to the ocean in other regions (Jeandel, 2016).

\section{Sampling and methods}

Seawater samples were collected from nine stations around the Tyrrhenian Sea, Strait of Sicily and Western Ionian Sea (central MS) during the NextData Cruise on the CNR-Minerva Uno research vessel (June 11th to 29th, 2016; Fig. 1; Table 1). Six stations were sampled at 6 depths (St. 1, 2, 4, 6, 7 and 8), one station at 4 depths (St. 3) and the two shallowest stations at 3 depths (St. 5 and 9). Seawater was collected from Niskin bottles on a CTD rosette and immediately filtered through $0.45 \mu \mathrm{m}$ Acropak Supor filter membranes into acid-clean $10 \mathrm{~L}$ cubitainers, followed by acidification at $\mathrm{pH}=2$ with ultrapure Optima $\mathrm{HCl}$ and stored until analysis in the home laboratory. Incidentally, half of the sample from $800 \mathrm{~m}$ depth at station 2 (one of the two 5L container) was not filtered before acidification, what could induce release of REE from particles to the dissolved phase during the chemical treatment.

\subsection{Analytical methods}

For the Nd isotopic analyses, filtered seawater (9-9.5 L per sample) was pre-concentrated using SEP-PAK C18 cartridges impregnated with HDEHP.H2.MEHP complexing agent (Shabani et al., 1992). Major fraction of barium was eliminated with $\mathrm{HCl} 0.01 \mathrm{M}$ and REE eluted with $\mathrm{HCl} 6 \mathrm{M}$. After evaporation, a chromatographic extraction using cationic resin (Dowex AG 50WX8) was used to separate the REEs from major ions and a final purification with anionic Ln resin was performed (Pin and Zalduegui, 1997).

Measurements of $\varepsilon_{\mathrm{Nd}}$ were carried out in the Centros Científicos y Tecnológicos de la Universidad de Barcelona (CCiTUB) on a new Plasma 3 Multi Collector Inductively Coupled Plasma Mass Spectrometer (Nu Instruments). Samples (dissolved in 2\% Optima grade HNO3) were injected into the plasma source through a Cetac Aridus 2 desolvating device. Signals for the background, procedural blanks and isobaric Sm interferences were appropriately subtracted. The procedural blanks ranged from 15 to $25 \mathrm{pg}$, three orders of magnitude lower than the typical Nd abundance in our seawater samples (13-28 ng), and their effects on the final sample uncertainty were negligible. The mass bias correction of the ${ }^{143} \mathrm{Nd} /{ }^{144} \mathrm{Nd}$ ratios was carried out using the exponential model (Wombacher and Rehkämper, 2003) applying the reference ${ }^{146} \mathrm{Nd} /{ }^{144} \mathrm{Nd}$ value of 0.7219 . Isotopic compositions $\left({ }^{143} \mathrm{Nd} /{ }^{144} \mathrm{Nd}\right)$ were determined using the sample-standard bracketing technique with the JNdi-1 reference standard (0.512115 \pm 0.000007 ; Tanaka et al., 2000). Uncertainties in $\varepsilon_{\mathrm{Nd}}$ values were estimated from the external reproducibility ( $2 \mathrm{sd}$ ) determined by repeat JNdi- 1 measurements from each session. They range from 7 to $14 \mathrm{ppm}$ (i.e., from 0.14 to 0.28 epsilon units). Duplicate samples from the same depth but different Niskin bottles $(n=3)$ were not significantly different within 0.28 epsilon unit.

Subsamples for dissolved REE analyses were collected in $500 \mathrm{ml}$ acid-clean polypropylene bottles in the laboratory, where they were spiked with commercial ${ }^{150} \mathrm{Nd}(97.84 \%)$ and ${ }^{172} \mathrm{Yb}(94.9 \%)$. A purified Fe solution was also added and the $\mathrm{pH}$ was increased to 7-8 with ultrapure $\mathrm{NH}_{4} \mathrm{OH}$ to induce REE co-precipitation with iron hydroxides. The bulk of the supernatant was discarded and the remaining precipitate carefully rinsed and centrifuged several times to eliminate salts. The recovered REE- $\mathrm{Fe}(\mathrm{OH})_{3}$ were redissolved and loaded on an anion exchange column (AG1x8 resin) to isolate REE from Fe (Lacan and Jeandel, 2001). Samples were finally dissolved in $\mathrm{HNO}_{3} 1.5 \%$ and doped with In and Re internal standards for instrumental drift correction.

The Inductively Coupled Plasma Mass Spectrometer (ICP-MS) used for the dissolved REE concentration analyses was an Agilent $7500 \mathrm{CE}$. All REE were determined by the external standard method, whereas Nd and $\mathrm{Yb}$ were additionally determined by isotope dilution, following Lacan and Jeandel (2001). The analytical recoveries ranged from $79 \%$ to $95 \%$. Signals from procedural blanks ranged from 0 to $1 \%$ for all the REE and sample-to-background signal ratios ranged from 100 to 18000 . The percentages of oxide and hydroxide formations (from 0 to $4 \%$ for all the REE) were accurately subtracted. Results of duplicate samples from the same depth but different Niskin bottles $(n=3)$ differed by 1 to $6 \%$. Accuracy assessed from measurements of the intercalibrated Bermuda Atlantic Time-Series Station (BATS 15 m; van de Flierdt., 2012) resulted in $1-3 \%$ for all the REE.

\subsection{Optimum Multi parameter analysis (OMPA)}

In this study, we applied a modified version of Optimum Multi Parameter Analysis (OMPA) method (Poole and Tomczak, 1999) to identify the relative abundances of the different water masses recognized over the central Mediterranean area. This method is a constrained non-negative least squares solution to the fraction of water types for a given depth and location based on observed conservative hydrographic properties and the assignment of the "end-member" characteristics of the individual water types. We considered standard hydrographic parameters such as potential temperature, salinity and dissolved oxygen together with HREEn (PAAS-normalized HREE) and $\varepsilon_{\text {Nd }}$ (Table 2; see the Discussion section 4.3. for more details). The method is "constrained" in that the fractional water type contribution must be zero or positive and less than unity. We chose to use proximal (i.e., from our set of data) end-members because using distal ones would require accounting for mixing with other potential water types. Thus, we are mindful of selecting more distal end-members would derive in different proportions (Jenkins et al., 2015). Since we do not measure all the tracers with the same precision, we need to weight the different equations thereby adjusting the contribution of each tracer equation (and the conservation equation) to the least squares constraint. Weighting of the equations is an important consideration (Glover et al., 2011; Poole and Tomczak, 1999) although within 
Table 1

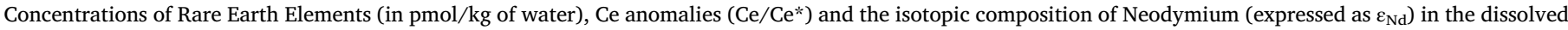

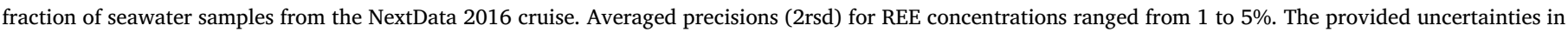

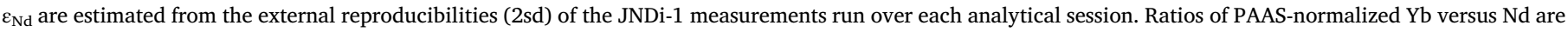
also given $\left(\mathrm{Yb}_{\mathrm{n}} / \mathrm{Yb}_{\mathrm{n}}\right)$.

\begin{tabular}{|c|c|c|c|c|c|c|c|c|c|c|c|c|c|c|c|c|c|}
\hline depth (m) & $\mathrm{La}$ & $\mathrm{Ce}$ & $\operatorname{Pr}$ & $\mathrm{Nd}$ & $\mathrm{Sm}$ & $\mathrm{Eu}$ & $\mathrm{Gd}$ & $\mathrm{Tb}$ & Dy & Ho & Er & $\mathrm{Tm}$ & $\mathrm{Yb}$ & $\mathrm{Lu}$ & $\mathrm{Ce} / \mathrm{Ce} *$ & $\varepsilon_{\mathrm{Nd}} \pm 2 \mathrm{sd}$ & $\mathrm{Yb}_{\mathrm{n}} / \mathrm{Nd}_{\mathrm{n}}$ \\
\hline \multicolumn{18}{|c|}{ St. $138^{\circ} 11^{\prime} 55.29^{\prime \prime} \mathrm{N}, 18^{\circ} 07^{\prime} 44.47^{\prime \prime} \mathrm{E}$} \\
\hline 2718 & 20.33 & 8.35 & 4.26 & 19.19 & 4.43 & 1.28 & 6.52 & 1.09 & 8.29 & 2.09 & 7.05 & 1.05 & 6.77 & 1.21 & 0.27 & $-6.65 \pm 0.28$ & 5.1 \\
\hline 800 & 22.03 & 9.51 & 4.64 & 21.34 & 5.10 & 1.45 & 7.35 & 1.23 & 9.18 & 2.30 & 7.73 & 1.12 & 7.31 & 1.29 & 0.29 & $-7.17 \pm 0.25$ & 4.9 \\
\hline 300 & 24.29 & 9.64 & 5.11 & 23.74 & 5.47 & 1.53 & 8.25 & 1.36 & 10.10 & 2.52 & 8.16 & 1.20 & 7.73 & 1.33 & 0.27 & $-6.60 \pm 0.25$ & 4.7 \\
\hline 200 & 25.49 & 14.15 & 5.35 & 25.01 & 5.72 & 1.56 & 8.55 & 1.38 & 10.21 & 2.54 & 8.25 & 1.18 & 7.68 & 1.32 & 0.39 & $-7.29 \pm 0.25$ & 4.4 \\
\hline 85 & 25.06 & 17.48 & 5.39 & 24.93 & 5.67 & 1.54 & 8.38 & 1.35 & 9.95 & 2.48 & 8.04 & 1.15 & 7.42 & 1.28 & 0.47 & $-7.76 \pm 0.25$ & 4.3 \\
\hline 25 & 27.17 & 26.71 & 5.80 & 26.73 & 6.02 & 1.62 & 8.66 & 1.39 & 10.09 & 2.47 & 7.92 & 1.14 & 7.38 & 1.26 & 0.66 & $-9.05 \pm 0.16$ & 4.0 \\
\hline \multicolumn{18}{|c|}{ St. $236^{\circ} 15^{\prime} 36.91^{\prime \prime} \mathrm{N}, 17^{\circ} 44^{\prime} 59.17^{\prime \prime} \mathrm{E}$} \\
\hline 3611 & 23.49 & 6.83 & 4.82 & 22.03 & 5.05 & 1.44 & 7.20 & 1.19 & 8.78 & 2.28 & 7.50 & 1.11 & 7.19 & 1.25 & 0.20 & $-6.73 \pm 0.25$ & 4.7 \\
\hline 800 & 27.16 & 14.73 & 5.74 & 25.97 & 6.02 & 1.69 & 8.52 & 1.39 & 10.20 & 2.58 & 8.36 & 1.20 & 7.75 & 1.36 & 0.36 & $-7.12 \pm 0.16$ & 4.3 \\
\hline 280 & 25.15 & 10.42 & 5.34 & 24.82 & 5.65 & 1.62 & 8.65 & 1.41 & 10.56 & 2.62 & 8.63 & 1.25 & 7.91 & 1.38 & 0.28 & $-6.41 \pm 0.25$ & 4.6 \\
\hline 200 & 25.85 & 14.01 & 5.48 & 25.39 & 5.73 & 1.62 & 8.65 & 1.40 & 10.40 & 2.56 & 8.45 & 1.20 & 7.62 & 1.32 & 0.37 & $-7.19 \pm 0.25$ & 4.3 \\
\hline 130 & 24.94 & 18.12 & 5.34 & 24.60 & 5.63 & 1.53 & 8.29 & 1.34 & 9.88 & 2.46 & 7.93 & 1.14 & 7.42 & 1.26 & 0.49 & $-7.91 \pm 0.25$ & 4.3 \\
\hline 40 & 24.66 & 23.00 & 5.26 & 24.32 & 5.50 & 1.50 & 8.20 & 1.29 & 9.54 & 2.36 & 7.68 & 1.09 & 7.03 & 1.21 & 0.63 & $-8.12 \pm 0.25$ & 4.2 \\
\hline \multicolumn{18}{|c|}{ St. $336^{\circ} 31^{\prime} 18.09^{\prime \prime} \mathrm{N}, 13^{\circ} 14^{\prime} 40.91^{\prime \prime} \mathrm{E}$} \\
\hline 1692 & 20.77 & 8.51 & 4.06 & 18.68 & 4.29 & 1.27 & 6.52 & 1.09 & 8.38 & 2.18 & 7.28 & 1.07 & 6.93 & 1.22 & 0.30 & $-7.04 \pm 0.25$ & 5.3 \\
\hline 300 & 23.69 & 8.33 & 4.95 & 22.60 & 5.24 & 1.45 & 7.86 & 1.28 & 9.58 & 2.40 & 7.77 & 1.16 & 7.26 & 1.28 & 0.24 & $-7.01 \pm 0.25$ & 4.6 \\
\hline 120 & 23.74 & 15.27 & 5.04 & 23.50 & 5.35 & 1.43 & 7.79 & 1.25 & 8.93 & 2.20 & 7.11 & 1.00 & 6.45 & 1.11 & 0.44 & $-8.90 \pm 0.25$ & 4.0 \\
\hline 75 & 25.06 & 19.33 & 5.43 & 24.78 & 5.68 & 1.55 & 7.81 & 1.20 & 8.42 & 2.03 & 6.52 & 0.90 & 5.47 & 0.94 & 0.50 & $-9.52 \pm 0.25$ & 3.2 \\
\hline \multicolumn{18}{|c|}{ St. $439^{\circ} 21^{\prime} 23.10^{\prime \prime} \mathrm{N}, 13^{\circ} 54^{\prime} 03.60^{\prime \prime} \mathrm{E}$} \\
\hline 3497 & 22.13 & 6.34 & 4.50 & 20.47 & 4.79 & 1.34 & 6.71 & 1.10 & 7.85 & 1.96 & 6.45 & 0.93 & 5.87 & 1.04 & 0.20 & $-8.54 \pm 0.25$ & 4.1 \\
\hline 1500 & 22.84 & 7.86 & 4.70 & 21.26 & 4.84 & 1.41 & 6.94 & 1.13 & 8.15 & 2.00 & 6.71 & 0.97 & 6.31 & 1.09 & 0.23 & $-8.20 \pm 0.25$ & 4.3 \\
\hline 900 & 21.29 & 7.69 & 4.27 & 19.34 & 4.53 & 1.24 & 6.57 & 1.09 & 7.92 & 1.99 & 6.69 & 0.97 & 6.18 & 1.07 & 0.25 & $-7.68 \pm 0.25$ & 4.6 \\
\hline 400 & 22.65 & 8.31 & 4.59 & 20.60 & 4.93 & 1.46 & 7.20 & 1.16 & 8.64 & 2.17 & 7.22 & 1.02 & 6.60 & 1.19 & 0.25 & $-7.62 \pm 0.25$ & 4.6 \\
\hline 95 & 27.41 & 15.42 & 5.57 & 24.97 & 5.82 & 1.56 & 8.25 & 1.29 & 9.31 & 2.26 & 7.37 & 1.05 & 6.43 & 1.13 & 0.38 & $-8.61 \pm 0.25$ & 3.7 \\
\hline 25 & 28.69 & 26.61 & 6.07 & 27.00 & 6.29 & 1.72 & 8.70 & 1.31 & 9.16 & 2.21 & 6.96 & 0.99 & 5.97 & 1.03 & 0.59 & $-9.16 \pm 0.16$ & 3.2 \\
\hline \multicolumn{18}{|c|}{ St. $542^{\circ} 03^{\prime} 39.96^{\prime \prime} \mathrm{N}, 11^{\circ} 14^{\prime} 44.94^{\prime \prime} \mathrm{E}$} \\
\hline 360 & 25.34 & 10.10 & 5.22 & 23.04 & 5.14 & 1.52 & 7.25 & 1.19 & 8.73 & 2.19 & 7.20 & 1.03 & 6.84 & 1.18 & 0.26 & $-7.72 \pm 0.25$ & 4.3 \\
\hline 240 & 26.31 & 10.38 & 5.43 & 24.36 & 5.51 & 1.56 & 7.73 & 1.29 & 9.31 & 2.30 & 7.48 & 1.07 & 7.00 & 1.20 & 0.26 & $-7.81 \pm 0.25$ & 4.1 \\
\hline 40 & 38.32 & 35.43 & 7.95 & 34.35 & 7.40 & 2.00 & 10.01 & 1.51 & 10.32 & 2.45 & 7.69 & 1.06 & 6.69 & 1.15 & 0.58 & $-8.70 \pm 0.16$ & 2.8 \\
\hline \multicolumn{18}{|c|}{ St. $643^{\circ} 32^{\prime} 42.59^{\prime \prime} \mathrm{N}, 08^{\circ} 50^{\prime} 14.94^{\prime \prime} \mathrm{E}$} \\
\hline 2264 & 22.60 & 7.28 & 4.80 & 21.94 & 5.19 & 1.56 & 7.07 & 1.14 & 8.36 & 2.08 & 6.79 & 0.98 & 6.41 & 1.11 & 0.21 & $-8.68 \pm 0.14$ & 4.2 \\
\hline 1000 & 23.15 & 7.24 & 4.69 & 20.97 & 4.95 & 1.48 & 6.79 & 1.14 & 8.10 & 2.01 & 6.70 & 0.95 & 6.13 & 1.08 & 0.21 & $-8.61 \pm 0.14$ & 4.2 \\
\hline 580 & 24.15 & 7.61 & 4.87 & 22.06 & 5.22 & 1.58 & 7.11 & 1.20 & 8.67 & 2.12 & 7.19 & 1.01 & 6.68 & 1.17 & 0.22 & $-8.26 \pm 0.14$ & 4.4 \\
\hline 350 & 24.79 & 7.32 & 5.05 & 22.83 & 5.27 & 1.48 & 7.36 & 1.23 & 8.90 & 2.23 & 7.20 & 1.04 & 6.63 & 1.18 & 0.20 & $-8.24 \pm 0.16$ & 4.2 \\
\hline 140 & 28.10 & 9.88 & 5.79 & 25.92 & 5.77 & 1.71 & 8.14 & 1.30 & 9.43 & 2.27 & 7.61 & 1.05 & 6.81 & 1.13 & 0.23 & $-8.84 \pm 0.16$ & 3.8 \\
\hline 45 & 27.44 & 13.98 & 5.57 & 24.73 & 5.73 & 1.68 & 8.19 & 1.24 & 8.99 & 2.19 & 7.00 & 1.00 & 6.29 & 1.09 & 0.34 & $-8.97 \pm 0.16$ & 3.7 \\
\hline \multicolumn{18}{|c|}{ St. $740^{\circ} 55^{\prime} 49.11^{\prime \prime} \mathrm{N}, 10^{\circ} 37^{\prime} 26.63^{\prime \prime} \mathrm{E}$} \\
\hline 2293 & 20.52 & 6.52 & 4.15 & 19.36 & 4.48 & 1.21 & 6.53 & 1.04 & 7.78 & 1.96 & 6.42 & 0.94 & 6.14 & 1.10 & 0.23 & $-8.30 \pm 0.16$ & 4.6 \\
\hline 1000 & 20.25 & 7.81 & 4.05 & 18.91 & 4.32 & 1.17 & 6.43 & 1.07 & 7.85 & 2.02 & 6.67 & 0.97 & 6.31 & 1.15 & 0.28 & $-9.38 \pm 0.16$ & 4.8 \\
\hline 400 & 23.76 & 8.32 & 4.88 & 21.96 & 5.13 & 1.57 & 7.41 & 1.23 & 8.82 & 2.23 & 7.34 & 1.08 & 6.87 & 1.20 & 0.24 & $-7.60 \pm 0.28$ & 4.5 \\
\hline 240 & 24.63 & 9.44 & 5.15 & 23.13 & 5.38 & 1.56 & 7.85 & 1.25 & 9.33 & 2.32 & 7.59 & 1.09 & 6.96 & 1.20 & 0.25 & $-7.77 \pm 0.28$ & 4.3 \\
\hline 100 & 28.53 & 14.73 & 5.85 & 26.23 & 5.93 & 1.69 & 8.51 & 1.35 & 9.49 & 2.34 & 7.30 & 1.08 & 6.89 & 1.21 & 0.35 & $-8.33 \pm 0.16$ & 3.8 \\
\hline 50 & 28.12 & 21.37 & 6.89 & 29.50 & 6.00 & 1.63 & 8.45 & 1.32 & 9.37 & 2.11 & 6.83 & 0.96 & 6.22 & 1.03 & 0.40 & $-8.86 \pm 0.16$ & 3.0 \\
\hline \multicolumn{18}{|c|}{ St. $838^{\circ} 47^{\prime} 00.63^{\prime \prime} \mathrm{N}, 10^{\circ} 42^{\prime} 26.70^{\prime \prime} \mathrm{E}$} \\
\hline 2409 & 23.49 & 6.29 & 4.56 & 20.97 & 4.64 & 1.34 & 7.17 & 1.10 & 8.00 & 1.99 & 6.49 & 0.92 & 6.01 & 1.08 & 0.20 & $-8.49 \pm 0.28$ & 4.1 \\
\hline 1000 & 21.23 & 7.75 & 4.13 & 19.59 & 4.54 & 1.35 & 6.15 & 1.03 & 7.62 & 1.83 & 6.14 & 0.88 & 5.96 & 1.00 & 0.28 & $-7.78 \pm 0.28$ & 4.4 \\
\hline 300 & 24.22 & 7.85 & 4.76 & 22.63 & 5.10 & 1.59 & 7.28 & 1.18 & 8.71 & 2.04 & 6.91 & 0.97 & 6.70 & 1.11 & 0.25 & $-7.60 \pm 0.28$ & 4.3 \\
\hline 100 & 26.27 & 11.13 & 5.37 & 25.40 & 5.73 & 1.83 & 8.59 & 1.32 & 9.53 & 2.26 & 7.24 & 1.01 & 6.88 & 1.16 & 0.31 & $-9.31 \pm 0.16$ & 3.9 \\
\hline 60 & 24.80 & 14.44 & 5.00 & 23.24 & 5.22 & 1.40 & 7.76 & 1.23 & 8.94 & 2.21 & 7.25 & 1.03 & 6.51 & 1.15 & 0.42 & $-8.79 \pm 0.28$ & 4.0 \\
\hline 25 & 26.53 & 22.99 & 5.45 & 25.21 & 5.64 & 1.48 & 8.08 & 1.26 & 9.03 & 2.19 & 7.06 & 0.98 & 6.25 & 1.09 & 0.61 & $-9.39 \pm 0.28$ & 3.6 \\
\hline \multicolumn{18}{|c|}{ St. $938^{\circ} 00^{\prime} 00.12^{\prime \prime} \mathrm{N}, 11^{\circ} 47^{\prime} 00.30^{\prime \prime} \mathrm{E}$} \\
\hline 1036 & 19.94 & 6.67 & 4.01 & 18.70 & 4.29 & 1.17 & 6.44 & 1.04 & 7.84 & 1.99 & 6.61 & 0.95 & 6.21 & 1.10 & 0.24 & $-9.04 \pm 0.28$ & 4.8 \\
\hline 400 & 21.52 & 7.98 & 4.31 & 20.15 & 4.66 & 1.30 & 7.16 & 1.19 & 8.99 & 2.31 & 7.58 & 1.11 & 7.15 & 1.27 & 0.27 & $-7.12 \pm 0.28$ & 5.1 \\
\hline 25 & 27.14 & 30.01 & 5.94 & 27.73 & 6.30 & 1.65 & 8.57 & 1.30 & 8.82 & 2.10 & 6.57 & 0.89 & 5.48 & 0.94 & 0.74 & $-9.89 \pm 0.16$ & 2.8 \\
\hline
\end{tabular}

Table 2

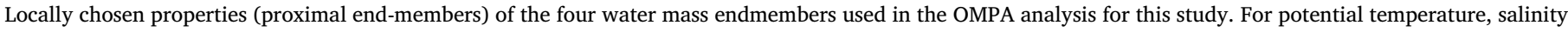

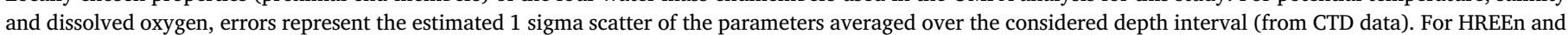

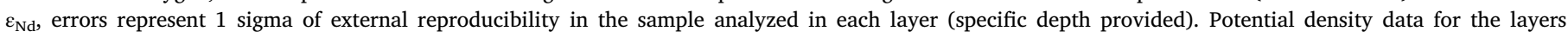
considered is also included.

\begin{tabular}{|c|c|c|c|c|c|c|c|c|c|}
\hline water mass & station & depth interval (m) & pot. density $\left(\mathrm{kg} \cdot \mathrm{m}^{-3}\right)$ & pot. temp. $\left({ }^{\circ} \mathrm{C}\right)$ & salinity & $\mathrm{O}_{2}\left(\mathrm{mg} \cdot \mathrm{L}^{-1}\right)$ & depth (m) & HREEn & $\varepsilon_{\mathrm{Nd}}$ \\
\hline MAW & 3 & $50-80$ & $27.43-27.82$ & $16.00 \pm 0.14$ & $37.467 \pm 0.020$ & $7.76 \pm 0.10$ & 75 & $2.35 \pm 0.01$ & $-9.52 \pm 0.12$ \\
\hline LIW & 2 & $200-300$ & $28.80-28-95$ & $15.72 \pm 0.11$ & $38.990 \pm 0.030$ & $6.93 \pm 0.09$ & 280 & $3.16 \pm 0.02$ & $-6.41 \pm 0.12$ \\
\hline EMDW & 2 & $2000-3600$ & 29.19-29.20 & $13.45 \pm 0.03$ & $38.731 \pm 0.003$ & $6.12 \pm 0.01$ & 3600 & $2.77 \pm 0.02$ & $-6.73 \pm 0.12$ \\
\hline WMDW & 8 & $1500-2400$ & $29.11-29.11$ & $13.04 \pm 0.07$ & $38.513 \pm 0.017$ & $5.91 \pm 0.08$ & 2400 & $2.40 \pm 0.06$ & $-8.49 \pm 0.14$ \\
\hline
\end{tabular}


reasonable limits, the exact choice does not strongly affect the outcome (Jenkins et al., 2015). The weights for each tracer equation are calculated considering the deviation of property values from their average and the largest source water variance among the end-members (following Frants et al 2013), here leaving MAW aside due to the strong variations in physico-chemical properties of these surface waters. A weight for the mass conservation equation cannot be calculated in the same way because it is not based on any measurements although it ensures that mass conservation is well represented in the solution. The weighting of the conservation equation denotes the degree to which the sum of the water type contributions may not be exactly 1 . Since the other tracer constraints are properly standardized and the water mass mixing model is structured from the interpretation of the $\theta$-S diagrams, we have adopted the criteria of accepting a $1 \%$ uncertainty on the unity-sum constraint, i.e., a weighting factor of 100 .

\section{Results}

The $\theta$-S diagrams (Fig. 1) mainly highlight the presence of four water masses: fresher MAW in the upper layer, intermediate westward flowing salty LIW, EMDW in the Ionian stations and WMDW in the Tyrrhenian and Ligurian Sea stations. A salinity section from St. 6 to St. 1 (comprising the stations, from NW to SE, 6, 5, 7, 4, 8, 9, 3, 2 and 1) is also illustrated in Fig. 1. Lowered surface temperatures at St.9 and St.3 confirm the direct influence of the MAW in the Strait of Sicily area. LIW coming from the eastern basin can be delineated by their salinity maximum at intermediate depths (from St. 1 to St.7).

\subsection{Dissolved Rare Earth element concentrations: Vertical profiles}

Dissolved concentrations of REE (Table 1) globally show variations from 30 to $50 \%$, excepting Ce that varies more than a $100 \%$. Total ranges (in pmol $\mathrm{kg}^{-1}$ ) fluctuate from 20 to 38 for La, 19 to 34 for Nd, 6 to 10 for Gd, 8 to 11 for Dy or 5 to 8 for $\mathrm{Yb}$ and they fall within typical open-ocean ranges (Haley et al., 2014). An exception is cerium given that it reaches particularly high levels in surface waters of our central MS stations (up to 35 pmol $\mathrm{kg}^{-1}$; Fig. 2; de Baar et al., 2018). The REE behavior generally observed in the open ocean reflects a "nutrient-like" shape, with increasing concentrations with depth (Elderfield, 1988, Jeandel et al., 2013, Abbot et al., 2015; Schijf et al., 2015). However, our dissolved REE vertical profiles in the central MS do not show such a pattern, likely reflecting the circulation of relatively young water masses (e.g., WMDW estimated age ranges from 20 to $35 \mathrm{y}$; Rhein and Hinrichsen, 1993; Flecha et al., 2019) with limited time to accumulate remineralized loads of dissolved REE (Crocket et al., 2018). Reasonably discriminated vertical profiles are displayed for LREE with comparison to HREE.

Concerning LREE, their contents are elevated in uppermost waters and rapidly decrease below, maintaining rather constant values with depth, sometimes recovering a bit (Fig. 2). An exception is the sample at $800 \mathrm{~m}$ depth of St. 2 where a significant increase is observed for LREE. Since half of the sampled water could not be filtered, this feature likely reflects LREE release from suspended particles to the dissolved fraction during the chemical treatment. The importance of filtration is hence highlighted in order to accurately interpret the obtained results. Dissolved cerium $\left(\mathrm{Ce}^{+3}\right)$ exhibits unique redox properties because it tends to be oxidized to the more particle reactive $\mathrm{Ce}^{+4}$ in seawater and thus scavenged. Consistently, measured dissolved Ce concentrations display surface maxima in all the stations, followed by a rapid decrease underneath. From intermediate waters (approx. $500 \mathrm{~m}$ depth) to the bottom, cerium remains pretty homogeneous everywhere (overall average $7.9 \pm 2.0 \mathrm{pmol} \cdot \mathrm{kg}^{-1}$ ).

As for HREE, they exhibit lower levels at the surface and they peak at intermediate waters to decrease again with depth (Fig. 2). While concentrations of LREE are less variable in the whole set of sampled stations, HREE reveal a gradual increase towards the east (Fig. 2). Given the similarity within individual LREE and HREE vertical distributions, we will discuss the concentrations of all the LREE together and the same for the HREE.

\subsection{Dissolved Rare Earth element concentrations: shale-normalized patterns}

The patterns obtained after normalizing the REE data to the PAAS reference (Taylor and McLennan, 1985) are depicted in Figure S1 of Supplementary material (both in linear and log scales). They all reveal enrichments in HREE relative to LREE and negative cerium anomalies, consistent with the oceanic REE behaviors result of the balance between sorption/solution complexation and additional redox transformations in the case of Ce. PAAS-normalized REE patterns with depth within a given station are more similar in the Ionian Sea (St.1 and St. 2) and the Ligurian Sea (St. 6) than the rest of stations from the TYS and the Sicily Strait, where water masses from different origins mix. A particular scattered pattern is obtained for LREE in surface waters of the St. 5 (coastal station), where marked higher concentrations compared to the rest of the water column and the other stations are evidenced. Negative cerium anomalies are weak (higher values) at surface waters in all the stations, ranging from 0.34 to 0.74 , likely reflecting the influence of terrigenous input. Negative Ce anomalies become promptly stronger with depth, averaging $0.25 \pm 0.05$ (1sd) from $500 \mathrm{~m}$ depth to the bottom, more typical of open ocean values (de Baar et al., 2018).

\subsection{Isotopic compositions of $N d\left(\varepsilon_{N d}\right)$}

Nd isotopic compositions ( $\varepsilon_{\mathrm{Nd}}$ ) are reported in Table 1 and Fig. 2. In surface waters, $\varepsilon_{\mathrm{Nd}}$ range from -8 to -10 , with the most unradiogenic values measured at the Strait of Sicily stations (St. 3 and St. 9). These signals evolve to more radiogenic values at intermediate depths, where $\varepsilon_{\mathrm{Nd}}$ vary from -6 in the Ionian (St. 2) to -8 in the Ligurian (St. 6) stations. Deep waters ( $>1000 \mathrm{~m}$ ) are isotopically differentiated in two groups with values around $\varepsilon_{\mathrm{Nd}}=-6.8 \pm 0.2$ in the easternmost stations (St.1, 2 and 3) and $\varepsilon_{\mathrm{Nd}}=-8.5 \pm 0.5$ in the westernmost stations (St. 6, 7 and 8). The closest stations to the Strait of Sicily (St. 3 and St. 9) do not exhibit as radiogenic values as those simulated by Ayache et al., $2016\left(\varepsilon_{\mathrm{Nd}}\right.$ up to -5.8 at the intermediate layer).

\section{Discussion}

\subsection{Lithogenic imprint}

In concordance with much proximal continental input sources in the MS than in other open ocean waters, the influence of lithogenic input is reflected in the measured high concentrations of dissolved LREE at surface waters. This is supported by the large enrichments in dissolved cerium and the extremely weak negative cerium anomalies (values up to 0.74 ), probably indicating the influence of dissolved REE release from particulate material characterized by positive or absent $\mathrm{Ce}$ anomalies (e.g., de Baar et al., 1985; Sholkovitz et al., 1994; Bayon et al., 2004; Freslon et al., 2014). More particularly, the station closest to the continental shelf margin (i.e., St. 5 at only $38 \mathrm{~km}$ from the central Tyrrhenian coast) shows the strongest LREE excess in surface waters, with enrichments relative to surface waters of all the other stations ranging from $20 \%$ to $54 \%$ (Fig. 2). All these features provide evidence of LREE input from shelf sediments of the Italian coast. Since water is well oxygenated (dissolved $\mathrm{O}_{2}$ from 5.7 to $8.2 \mathrm{mg} \cdot \mathrm{L}^{-1}$ ), release of LREE from reduction of Fe-Mn oxides in the water column can be ruled out. Another possibility comprises an atmospheric input of LREE, which is indeed expected to happen and influence the water column in the central MS, as it has been documented for the western basin (Henry et al., 1994). Dust inputs in the central Mediterranean Sea come largely from the Sahara region and take place as pulse events (Guerzoni et al., 1997) and thus, their imprint in surface waters would not result in the 

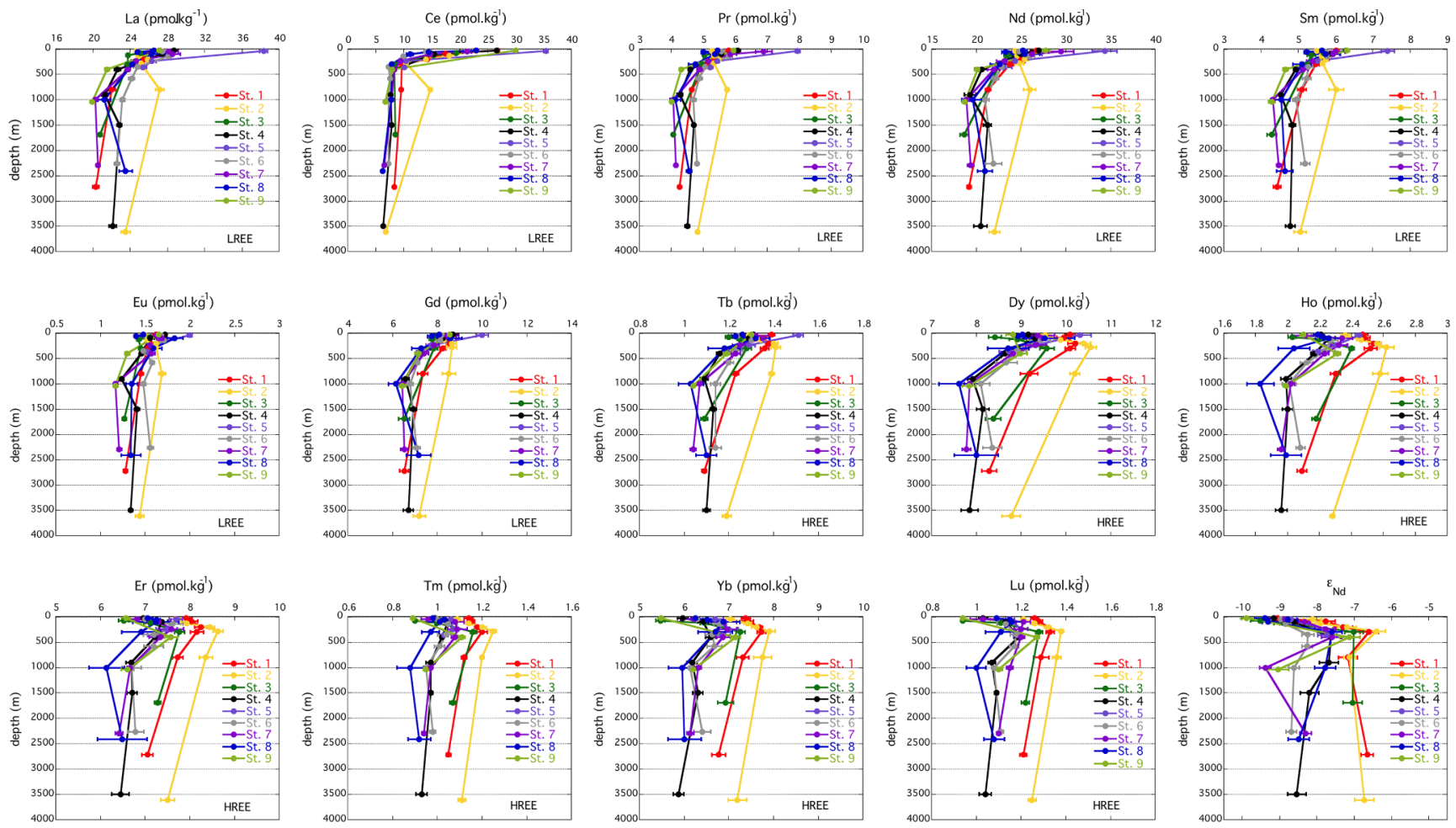

Fig. 2. Water column profiles of dissolved LREE and HREE concentrations (pmol- $\mathrm{kg}^{-1}$ of water) and isotopic composition of $\mathrm{Nd}\left(\varepsilon_{\mathrm{Nd}}\right)$. At $800 \mathrm{~m}$ depth in St. 2, half of the sampled water was not filtered and this could be the reason for the relative LREE peak.

obtained direct negative correlation of LREE with distance to the closest continental shelf for each station (not the African continent; Fig. S2, $\mathrm{R}=-0.95 ; \mathrm{p}=0.014)$. In addition, the average composition of Saharan dust of $\varepsilon_{\mathrm{Nd}}=-13.2 \pm 0.5$ (Aarons et al., 2013) is significantly different than our surface waters (from -8.7 to -9.2 ). Although likely of minor influence, locally originated dust inputs could indeed derive in the observed continental margin-dependence pattern. Another potential source of LREE could be the Submarine Groundwater Discharge (SGD) to the coastal zone (Johannesson et al., 2011). However, the lack of studies on SGD in the central Tyrrhenian continental shelf do not allow us to constrain any significant flux of dissolved REE associated to this process. In addition, dissolved patterns of REE in SGD fluxes do not show any LREE enrichment, but the opposite. Nevertheless, observational evidences of local submarine springs in the Southern TYS have been recently provided (Buongiorno Nardelli et al., 2017).

Therefore, the hypothesis of dissolved LREE release from continental margin sediments is the most plausible source to explain surface LREE excess, although a minor fraction of local dust inputs cannot be ruled out. Such submarine weathering of lithogenic material has been revealed to affect chemical budgets in other regions and for other chemical elements although not satisfactorily studied yet (Jeandel, 2016; Charette et al., 2018). Overall, the role of particulate material dissolution in seawater may be most significant in the cycles of sparingly soluble elements, which are more concentrated in particulate material (Jeandel and Oelkers, 2015). This is certainly in accordance with our results, where surface excess is observed for the more particlereactive light REE in contrast to the largely soluble HREE.

During the hypothesized particulate-seawater exchange in this study, no significant seawater $\varepsilon_{\mathrm{Nd}}$ modification is attained, contrarily to most studies reporting boundary exchange processes that drive to $\mathrm{Nd}$ isotopic shifts in contiguous seawater (Jeandel, 2016, van de Flierdt et al., 2016). This apparent controversy needs to be contrasted with the $\mathrm{Nd}$ signal in coastal sediments. Indeed, reported $\varepsilon_{\mathrm{Nd}}$ values measured in continental margin sediments and rocks of the Italian coast in the Tyrrhenian Sea average $-8.7 \pm 2.5(\mathrm{n}=194$; Ayache et al., 2016), entirely comprising the $\varepsilon_{\mathrm{Nd}}$ variation we have measured in surrounding surface waters ( $\varepsilon_{\mathrm{Nd}}$ from -8.7 to -9.2 in St. $4,5,6$ and 7). Therefore, despite the occurrence of continental inputs in the region, no significant modification of $\varepsilon_{\mathrm{Nd}}$ in MAW should be expected.

\subsection{Tracing water masses: Tracer signals}

From intermediate to deep waters, dissolved REE patterns display stronger negative cerium anomalies (Ce/Ce* from 0.20 to 0.30 ; Table 1 ) and a higher degree of HREE enrichment, e.g. PAAS-normalized $\mathrm{Yb} / \mathrm{Nd}$ ratios $\left(\mathrm{Yb}_{\mathrm{n}} / \mathrm{Nd}_{\mathrm{n}}\right)$ ranging from around 3 in surface waters to 4 or 5 at deep waters (Table 1). As mentioned above, vertical profiles of LREE (Fig. 2) suggest that LREE distributions are more sensible to external input sources and biogeochemical reactions in the water column than to horizontal water mass mixing. On the other hand, both HREE and $\varepsilon_{\mathrm{Nd}}$ exhibit rather analogous vertical profiles pointing to the same process predominantly affecting them: lower HREE concentrations and unradiogenic $\varepsilon_{\mathrm{Nd}}$ at surface waters, higher HREE concentrations and more radiogenic $\varepsilon_{\mathrm{Nd}}$ values at intermediate depths and returning to lower HREE and more negative $\varepsilon_{\mathrm{Nd}}$ values at deep waters. These changes are concordant with the presence of the different water masses in the region, as illustrated by the $\varepsilon_{\mathrm{Nd}}$ section (Fig. 3).

These structures seem to indicate that water mass mixing is governing the HREE and isotopic Nd distributions in the central MS. For example, the inflow of LIW from the Strait of Sicily to the Tyrrhenian Sea can be outlined through a HREE enrichment and a distinct radiogenic signal, with the purest end-member found in St. 2 $\left(\varepsilon_{\mathrm{Nd}}=-6.41 \pm 0.25 ; 280 \mathrm{~m}\right.$ depth$)$, as expected for its location (Fig. 1). The enhancement of HREE indicates older waters since HREE have longer residence times than LREE in the water column (Fowler et al., 1992), the latest being more particle reactive. Concerning the radiogenic isotopic Nd signal of LIW, it may reflect either partial dissolution of Nile river particles (Tachikawa et al., 2004) or the rock signature in the LIW formation zone (Ayache et al., 2016). Globally considering the MS water column, an addition of radiogenic Nd has 


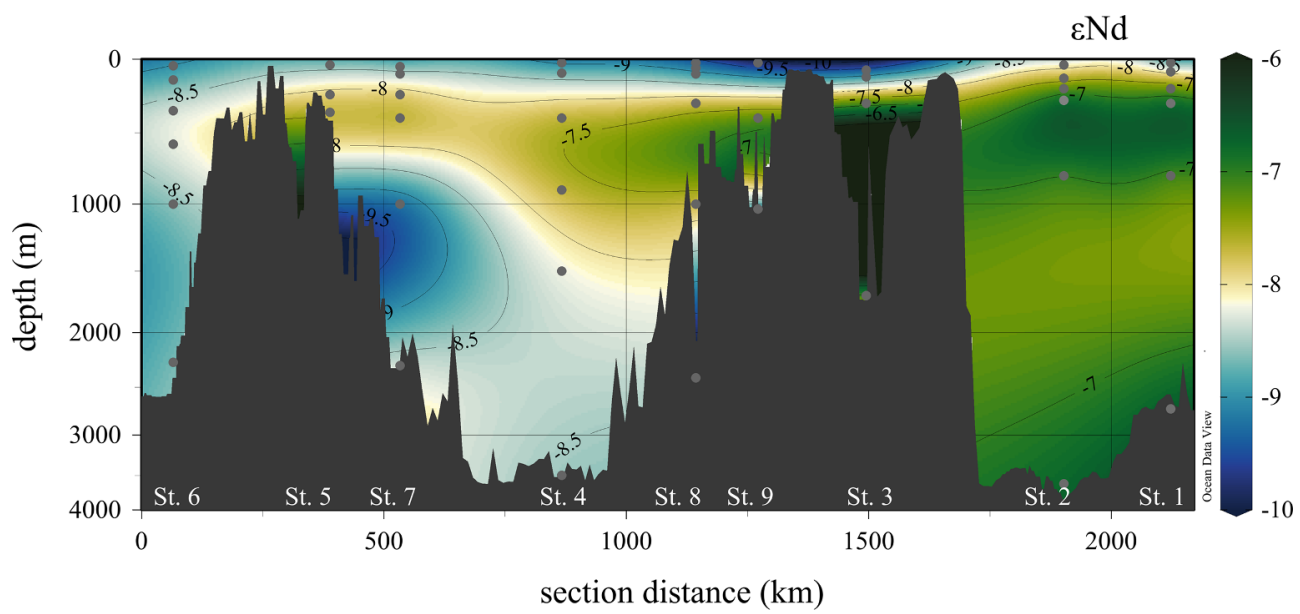

Fig. 3. Water column section of seawater $\varepsilon_{\mathrm{Nd}}$ values measured in the present study in the central MS.

been advocated in the literature given that $\mathrm{Nd}$ isotopic composition of Atlantic inflowing waters (-11.8; Spivack and Wasserburg 1988) is distinctly more negative (unradiogenic) than the Mediterranean Outflow Waters (MOW; $\varepsilon_{\mathrm{Nd}}=-9.5$; Henry et al., 1994, Tachikawa et al. 2004), thus implying a source of radiogenic Nd into Mediterranean waters.

Additionally, the measured HREE and $\varepsilon_{\mathrm{Nd}}$ at deep samples provide with a distinct signal between the two deep water masses: EMDW are imprinted by average $\varepsilon_{\mathrm{Nd}}=-6.9 \pm 0.2$ and present a $13 \%$ enrichment in HREE compared to WMDW, whose isotopic signal averages $\varepsilon_{\mathrm{Nd}}=-8.5 \pm 0.5$. WMDW is thought to flow into the TYS via the deepest part of the Sardinia-Sicily cross-section, where it gets overlaid with exiting modified TDW that leave the TYS between 700 and $1000 \mathrm{~m}$ (Astraldi and Gasparini, 1994). Looking at our closest station to the later region (St. 8), we observe non-significantly different HREE concentrations at $1000 \mathrm{~m}$ (TDW) and $2400 \mathrm{~m}$ (WMDW), but an isotopic Nd signal more radiogenic at $1000 \mathrm{~m}\left(\varepsilon_{\mathrm{Nd}}=-7.78 \pm 0.28\right)$ than at $2400 \mathrm{~m}\left(\varepsilon_{\mathrm{Nd}}=-8.49 \pm 0.28\right)$ and non-significantly different from the St. 4 signal at $900 \mathrm{~m}\left(\varepsilon_{\mathrm{Nd}}=-7.68\right)$, where it would be likely to find TDW. Unfortunately, our limited set of data does not allow us to go further in this distinction.

\subsection{Tracing water masses: Multi-parameter mixing model}

In order to examine the tentative conservative behavior of HREE (Zheng et al., 2016; Crocket et al., 2018) and $\varepsilon_{\mathrm{Nd}}$ (Goldstein and Hemming, 2003; Lambelet et al., 2016) as water mass tracers in the MS, we used the multi-parameter water mass analysis (OMPA method) described above to estimate the contributions of the four water masses recognized in the central MS. The properties of locally chosen water types (end-members) within the studied region are given in Table 2 and the resulting OMPA weights were of 15.8, 11.2, 5.7, 11.2 and 2.0 for potential temperature, salinity, dissolved oxygen, $\varepsilon_{\mathrm{Nd}}$ and HREEn equations. From our $\theta$-S diagrams, we have identified 4 different proximal water mass end-members and their potential temperature, salinity and dissolved oxygen properties averaged from the CTD casts ( $1 \mathrm{~m}$ resolution) as follows: MAW from 50 to $80 \mathrm{~m}$ depth in St. 3, LIW from 200 to $300 \mathrm{~m}$ in St. 2, WMDW from 1500 to the bottom $(2410 \mathrm{~m})$ in St. 8 and EMDW from 2000 down to the bottom $(3600 \mathrm{~m})$ in St.2. Concerning the HREEn and $\varepsilon_{\mathrm{Nd}}$ values for these end-members, we have considered the sample of the same station that fell into the depth range of each end-member (Table 2). The TDW has not been considered as an independent water mass because it is formed by mixing of water masses already included in the analysis (Millot, 2009, Vetrano et al. 2010; Falco et al., 2016). Since we have 4 different water masses, the OMPA method allows estimating water mass fractions with a minimum of three conservative tracers. Therefore, we can compare water mass fractions obtained in four scenarios i) considering the three oceanographic tracers alone (potential temperature, salinity and oxygen; TSOx only), ii) adding $\varepsilon_{\mathrm{Nd}}$ (with $\varepsilon_{N d}$ ) to the analysis, iii) including HREEn (with HREEn) and iv) considering the five parameters together (all). The obtained water mass fractions are displayed in Fig. 4 for MAW and LIW and Fig. 5 for WMDW and EMDW (data given in Table S1). Globally, the four scenarios show similarities in the distributions of the water mass fractions, in particular for the MAW. The congruent results give proof of the suitability of $\varepsilon_{\mathrm{Nd}}$ and HREE as conservative tracers for water mass mixing in the central MS. Residuals are kept very low in all the stations and depths, averaging $0.6 \pm 1.6 \%$ and only reach $9 \%$ at uppermost waters of St. 9 (Table S1). Sensitivity tested by decreasing the weighting factor for the mass conservation in one order of magnitude indicated averaged variations in water mass fractions from $2 \%$ to $14 \%$.

Consonant to the general circulation pattern (Millot, 1999), Modified Atlantic Waters are preferentially detected around the Strait of Sicily (St. 3 and 9) and the easternmost part of the TYS (St. 4), with fractions of this water mass as high as $80-100 \%$ in uppermost waters (Fig. 4; Table S1). Indeed, this water mass is detected in all the sampled stations with the weakest influence in the Ionian Sea ones (St. 1 and St. 2). At intermediate depths, LIW seems to be reasonably traced also when including the $\varepsilon_{\mathrm{Nd}}$ and HREEn parameters in the analysis and it appears as a delineated tongue at $200-800 \mathrm{~m}$ depth at the entire section of the central MS. This LIW layer seems to be tighter delimited when including both $\varepsilon_{\mathrm{Nd}}$ and HREEn as tracers (LIW all in Fig. 4) compared to TSOX only simulations. In particular, this narrowing is basically driven by $\varepsilon_{\text {Nd }}$ (LIW with $\varepsilon_{N d}$ in Fig. 4) since the sole inclusion of HREEn (LIW with HREEn) provides with a broader extension of LIW. This easternoriginated water mass spreads from the Ionian Sea stations (with contributions of $80 \%$ ) to the western MS, with representative fractions from 20 to $40 \%$ in the interior of the Tyrrhenian Sea (St. 4; Table S1). The distribution patterns for EMDW and WMDW fractions (Fig. 5; Table S1) also resemble in the four scenarios of the OMPA although some discrepancies have emerged when comparing OMPA results from the TSOx only setting and those obtained when including $\varepsilon_{\mathrm{Nd}}$ and/or HREEn. Concerning WMDW fractions derived when using all the parameters (WMDW all) and with $\varepsilon_{\mathrm{Nd}}\left(W M D W\right.$ with $\varepsilon_{N d}$; Fig. 5), they are alike and display the highest percentage of WMDW at the bottom of the TYS and Ligurian $(>80 \%)$ while intermediate fractions $(50-60 \%)$ are obtained in the TYS between 1000 and 2000 m depths. WMDW fractions in the TSOx and with HREEn scenarios are very similar and show greater WMDW contributions in the entire TYS water column (Fig. 5). It is to highlight that the presence of WMDW in the eastern basin is basically zero in all instances. The OMPA fractions obtained for EMDW (Fig. 5) are predominantly underlined in the Ionian Sea stations (St. 1 

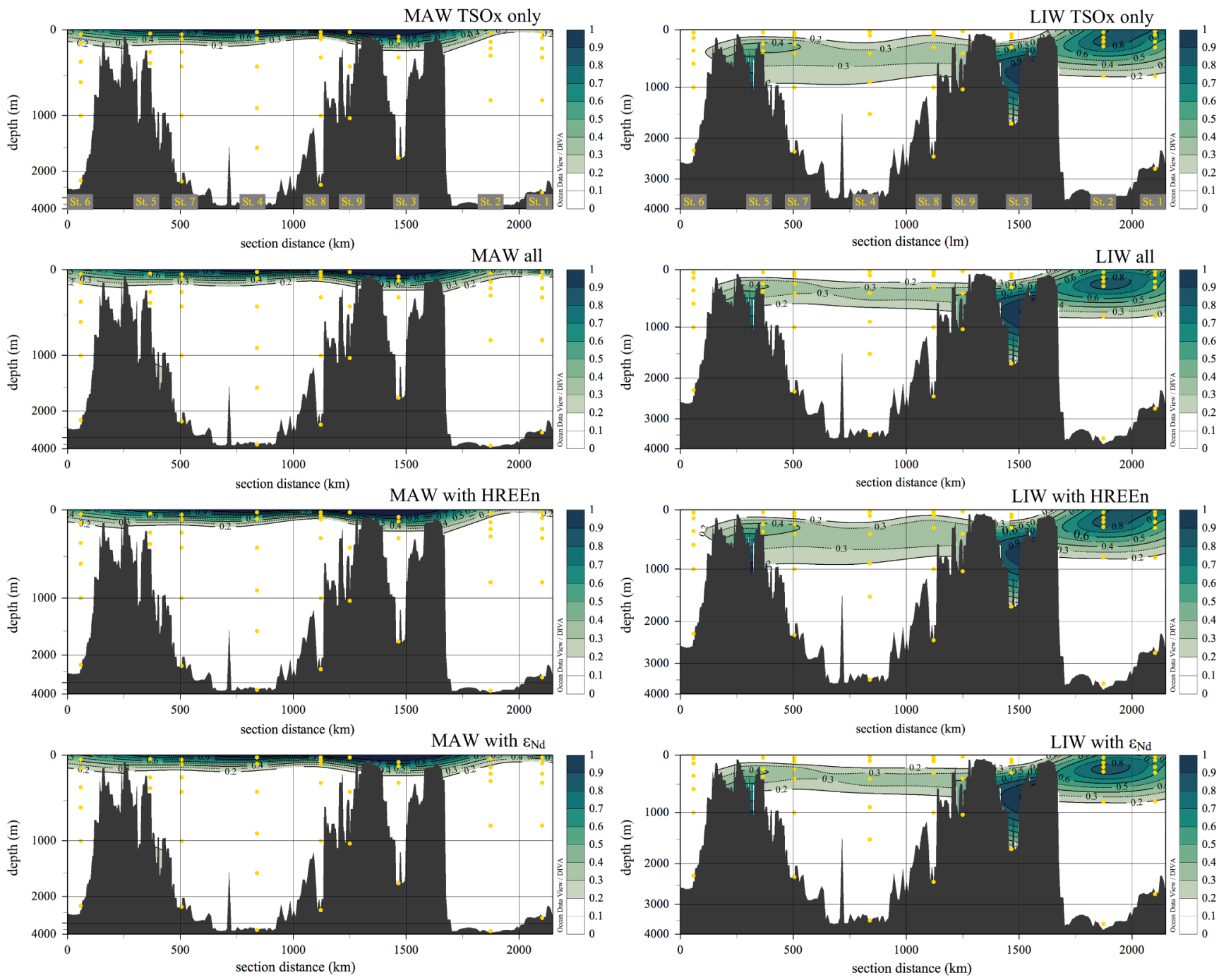

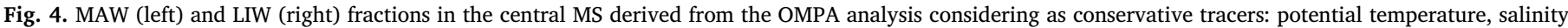

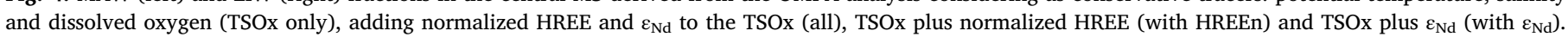
Sampled depths are indicated in yellow dots.

and St. 2) with proportions from 60 to $90 \%$, regardless of the conservative equations used. However, weak water column resolution hampers a better design of this water mass structure in that basin. The $E M D W$ all and $E M D W$ with $\varepsilon_{N d}$ scenarios give very comparable patterns, again indicating the greater influence of isotopic Nd, with EMDW fractions of up to $70 \%$ at $1000 \mathrm{~m}$ depth in the TYS. Both the TSOx only and with HREEn scenarios provide with minor EMDW presence in the TYS (basically $<40 \%$ at $400 \mathrm{~m}$ and $0 \%$ at $1000 \mathrm{~m}$ ). Contrarily to WMDW that is not detected in the eastern basin, the OMPA analysis prescribes the presence of the EMDW in the western basin and at different proportions depending on the setting, with opposite variations of the LIW and EMDW contributions among scenarios. Thereby, a more restricted LIW tongue in the western basin matches a wider and more prominent presence of EMDW crossing the Strait of Sicily when including $\varepsilon_{\mathrm{Nd}}$ in the OMPA analysis (all and with $\varepsilon_{N d}$ fractions compared with TSOx only and with HREEn scenarios). This again gives evidence of the isotopic Nd importance in the model, at least at the studied configuration of selected end-members and weighted equations. Indeed, from the correlation between salinity and seawater $\varepsilon_{\mathrm{Nd}}$, Tachikawa et al., (2004) already suggested that $\varepsilon_{\mathrm{Nd}}$ has a strongly conservative behavior in the Mediterranean Sea. Our results would contradict the traditional thesis of isolation between deep eastern and western MS basins maintained by some studies (Lascaratos et al., 1999). On the contrary, the significant contribution of EMDW in deep waters of the southeastern TYS is consistent with previous studies concluding that such a EMDW sinking process through the Strait of Sicily is possible because it is denser than the Tyrrhenian LIW $(\sigma \theta=29.10$ versus 29.05; Astraldi et al., 2001). Moreover, the present study would reinforce the hypothesis of a substantial Bernoulli aspiration in the Strait of Sicily of eastern deep waters involving the Ionian waters down to $1000 \mathrm{~m}$ (Iudicone et al., 2003). This would imply that deep layers of the eastern MS are renewed more efficiently than previously thought.

In order to check the global performance of the multiple regression analysis, we have used the OMPA-derived fractions including all the tracers to predict the values for the most conservative variables (potential temperature, salinity and dissolved oxygen) and compare them with the actually measured (Fig. $6 \mathrm{c}$, d and e). The agreement is noticeable except for surface waters, which are probably affected by either i) additional processes other than pure seawater mass mixing (e.g. lithogenic inputs or redox/scavenging processes occurring in the water column) or ii) a more challenging end-member characterization. The same approach can be applied to predict the seawater $\varepsilon_{\mathrm{Nd}}$ values, in this case assuming OMPA fractions obtained without accounting for $\varepsilon_{\mathrm{Nd}}$ so as to clearly separate the variables. The mean difference between 

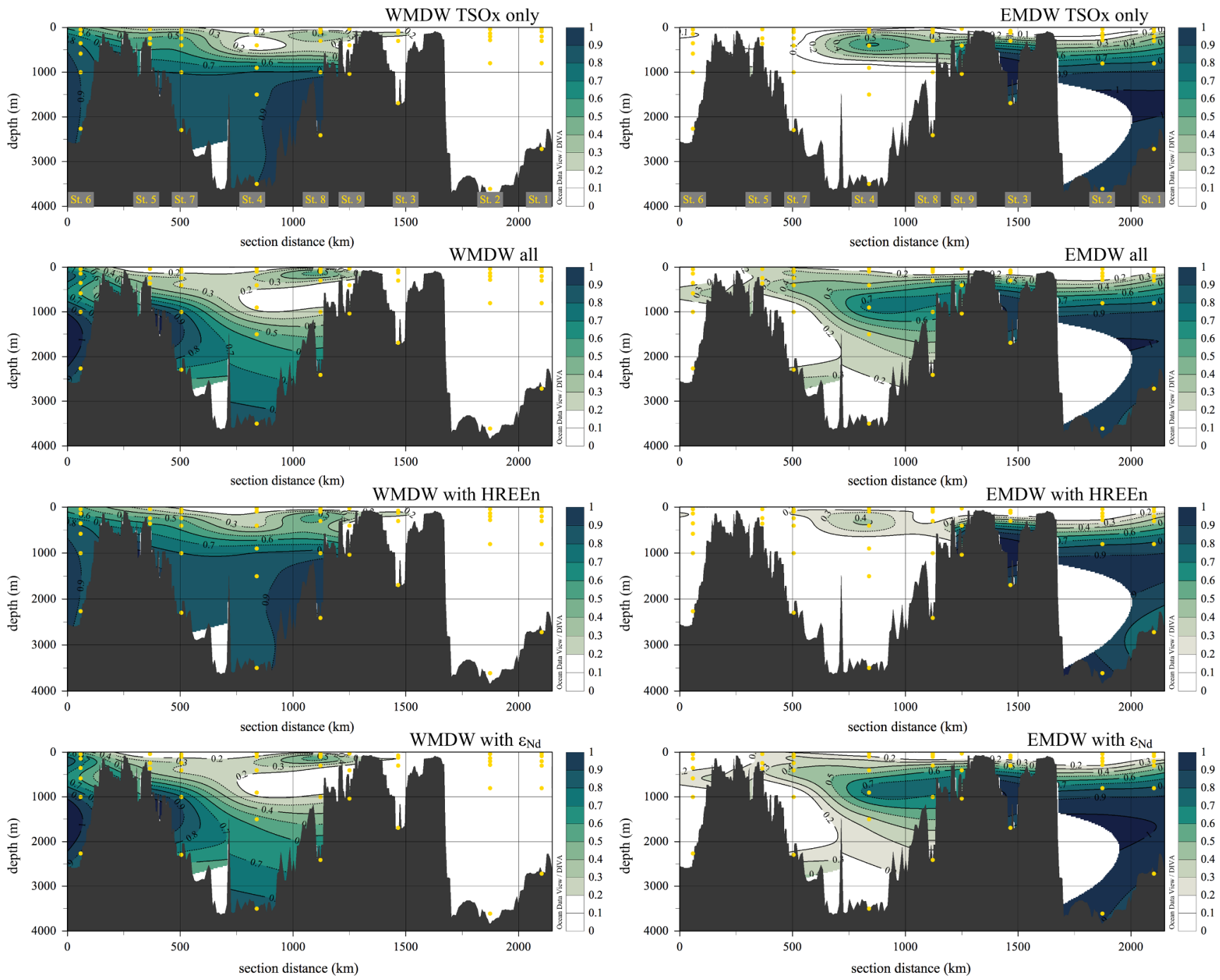

Fig. 5. WMDW (left) and EMDW (right) fractions in the central MS derived from the OMPA analysis considering as conservative tracers: potential temperature, salinity and dissolved oxygen (TSOx only), adding normalized HREE and $\varepsilon_{\mathrm{Nd}}$ to the TSOx (all), TSOx plus normalized HREE (with HREEn) and TSOx plus $\varepsilon_{\mathrm{Nd}}$ (with $\left.\varepsilon_{\mathrm{Nd}}\right)$. Sampled depths are indicated in yellow dots.

observed and predicted $\varepsilon_{\mathrm{Nd}}$ values is almost zero (Fig. 6 a) and residual values present a normal distribution (Fig. 6 b). Again, the major discrepancies (from 1.5 to 2 units) are depicted for surface waters close to the continental shelf (e.g. St. 5) and also at some bottom waters (e.g., St. 1 and St. 7), likely reflecting local/regional detrital influences.

\section{Conclusions}

We presented dissolved Rare Earth Elements (REE) and Nd isotopes from nine stations over the central Mediterranean Sea (MS). Although it consists of a limited data set, it is the first time that these geochemical tools are used in the region in order to better understand their conservative or non-conservative behavior in the MS. The obtained water column profiles of REE concentrations and $\varepsilon_{\mathrm{Nd}}$ in the central MS point to a general REE enrichment of Atlantic waters within their circulation around the basin, while becoming more radiogenic due to eastern-originated waters. Our data demonstrate a reasonable conservative behavior of HREE and $\varepsilon_{\mathrm{Nd}}$ and substantial non-conservative behavior of LREE and hence a decoupling of [Nd] and $\varepsilon_{\mathrm{Nd}}$ in all water masses of the central MS below the thermocline. We have revealed release of LREE from continental margin sediments on the Italian coast influencing surface waters close to the continent without a significant shift in $\varepsilon_{\mathrm{Nd}}$ during this process. Both HREE and $\varepsilon_{\mathrm{Nd}}$ displayed distinguished signals for the three water masses below the thermocline: LIW, EMDW and WMDW. The conservative behavior of these tracers for water mass mixing in the central MS has been successfully tested through a multiparameter mixing method, a modified OMPA analysis, and the relative contributions of water masses estimated using proximal end-members. We have applied recognized oceanographic tracers such as potential temperature, salinity and dissolved oxygen but also including the HREE and the isotopic composition of neodymium. Although with a limited data set, coherent water mass fractions have been derived in all the scenarios with some particularities included by the new tracers.

Water mass fractions derived from oceanographic parameters alone (potential temperature, salinity and dissolved oxygen) gave similar results than when considering HREE and/or $\varepsilon_{\mathrm{Nd}}$. MAW waters are quantified at surface waters $(<50 \mathrm{~m})$ through the whole section with proportions ranging from $30 \%$ in the Ionian Sea to $100 \%$ in the Strait of Sicily, in accordance to their known pathway and with weak variations among OMPA scenarios. The eastern-originated intermediate waters (LIW) flow to the central basin where we can find them with proportions of $20-40 \%$. This LIW layer is wider when traced via only TSOx parameters and when including HREEn in the model. Conversely, isotopic Nd produces a narrowing of LIW, favoring a stronger presence of 


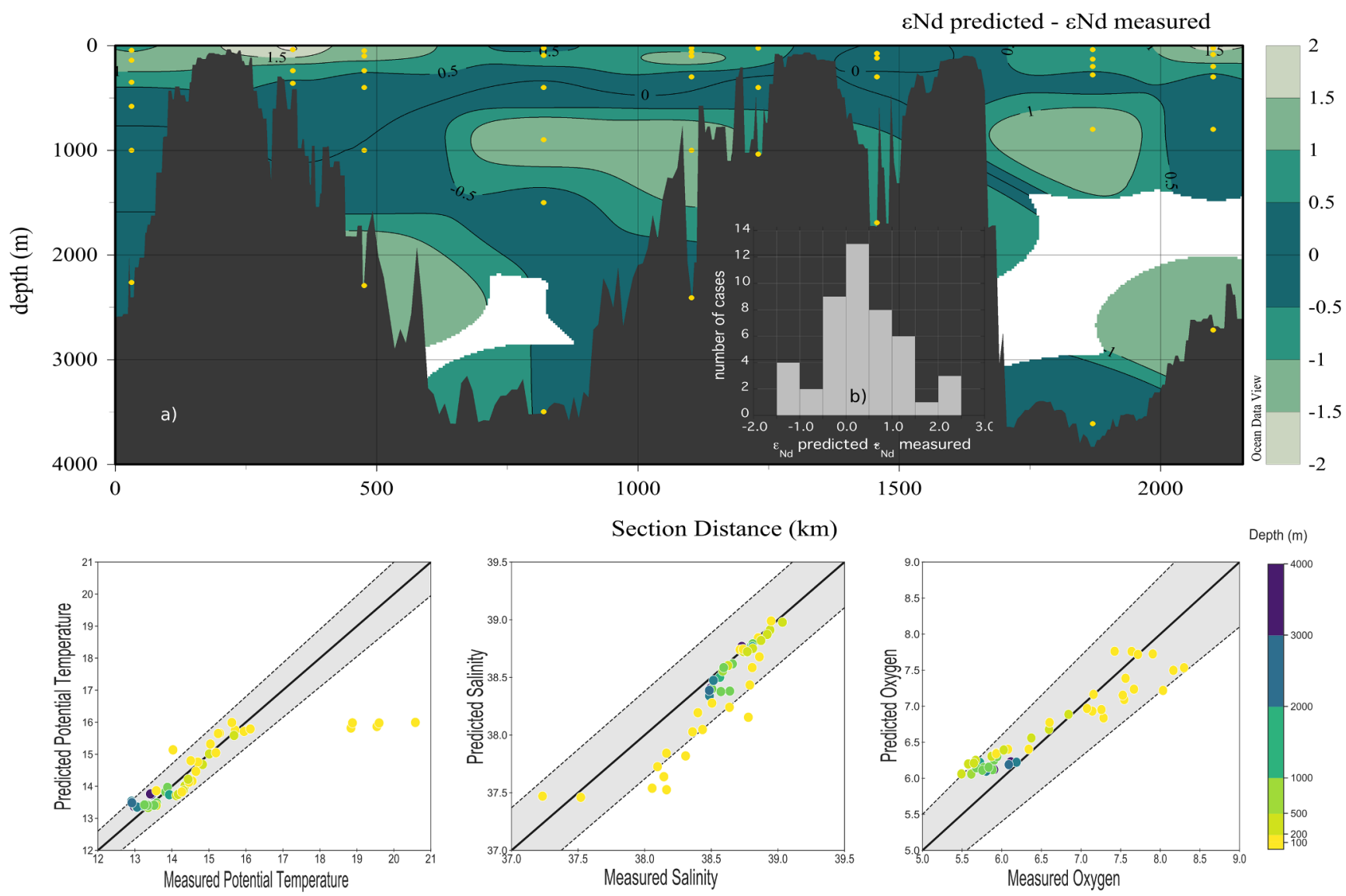

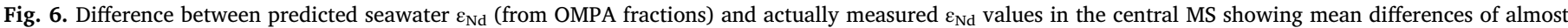

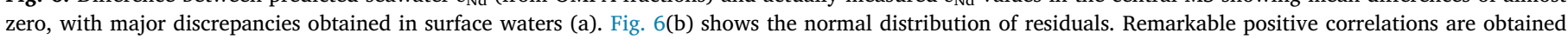

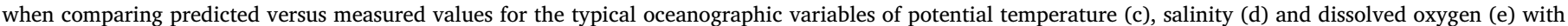
linear trends very close to the ideal 1:1 slope.

EMDW in the Tyrrhenian Sea. In this context, we propose that isotopic $\mathrm{Nd}$ helps the traditional oceanographic tracers in better defining the intrusion of radiogenic EMDW and reasonably locating them below the LIW. As expected, WMDW are only present at the western basin, irrespective of the set of tracers used in the OMPA analysis. However, their fractions are generally lower when including $\varepsilon_{\mathrm{Nd}}$ in the OMPA. Some unexpected WMDW significant fractions are obtained close to the surface, what probably reflects the limitation of the model when including thermocline (MAW) waters in the OMPA analysis.

\section{Acknowledgements}

This research has been financially supported by the TIMED Project funded by the European Commission (ERC Consolidator Grant to I. Cacho; ID: 683237). The authors thank financial support from the CHIMERA Project (CTM2016-75411-R), Generalitat de CatalunyaGrups de Recerca Consolidats (2017 SGR 315) and the Project of Strategic Interest NextData PNR 2011-2013 (www.nextdataproject.it). The water samples were collected during the NextData Cruise on R/V CNR-Minerva Uno in June 2016. E. Garcia-Solsona acknowledges support from a post-doctoral fellowship (FPDI-2013-15660) and L.D. Pena from the Ramón y Cajal program (MINECO, Spain). I. Cacho thanks the ICREA-Academia programme from the Generalitat de Catalunya. J.N. Pérez-Asensio has been funded by a Beatriu de Pinós postdoctoral fellowship from AGAUR (Generalitat de Catalunya) and the European Commission (Marie Curie-COFUND).

\section{Appendix A. Supplementary material}

Supplementary data to this article can be found online at https:// doi.org/10.1016/j.pocean.2020.102340.

\section{References}

Aarons, S.M., Aciego, S.M., Gleason, J.D., 2013. Variable Hf-Sr-Nd radiogenic isotopic compositions in a Saharan dust storm over the Atlantic: Implications for dust flux to oceans, ice sheets and the terrestrial biosphere. Chem. Geol. 349-350, 18-26.

Astraldi, M., Gasparini, G.P., 1994. The Seasonal Characteristics of the Circulation in the Tyrrhenian Sea. Seasonal and Interannual variability of the Western Mediterranean Sea. Coast. Estuar. Stud. 46, 115-134.

Astraldi, M., Gasparini, G.P., Gervasio, L., Salusti, E., 2001. Dense Water Dynamics along the Strait of Sicily (Mediterranean Sea). J. Phys. Oceanogr. 31, 3457-3475.

Astraldi, M., Gasparini, G.P., Vetrano, A., Vignudelli, S., 2002. Hydrographic characteristics and interanual variability of water masses in the central Mediterranean: a sensitivity test for long-term changes in the Mediterranean Sea. Deep-Sea Research I 49, 661-680.

Ayache, M., Dutay, J.-C., Arsouze, T., Révillon, S., Beuvier, J., Jeandel, C., 2016. High resolution neodymium characterization along the Mediterranean margins and modeling of "Nd distribution in the Mediterranean basins. Biogeosciences Discuss. https://doi.org/10.5194/bg-2016-109.

Bayon, G., German, C.R., Burton, K.W., Nesbitt, R.W., Rogers, N., 2004. Sedimentary $\mathrm{Fe}-\mathrm{Mn}$ oxyhydroxides as paleoceanographic archives and the role of aeolian flux in regulating oceanic dissolved REE. Earth Planet. Sci. Lett. 224, 477-492.

Bertram, C.J., Elderfield, H., 1993. The geochemical balances of the rare earth elements and neodymium isotopes in the oceans. Geochim. Cosmochim. Acta 57, 1957-1986.

Buongiorno Nardelli, B., Budillon, F., Watteaux, R., Ciccone, F., Conforti, A., De Falco, G., Di Martino, G., Innangi, S., Tonielli, R., Iudicone, D., 2017. Pockmark morphology and turbulent buoyant plumes at a submarine spring. Cont. Shelf Res. 148, 19-36.

Byrne, R.H., Kim, K.-H., 1990. Rare earth element scavenging in seawater. Geochim. Cosmochim. Acta 54, 2645-2656.

Charette, M.A., Lam, P.J., Lohan, M.C., Kwon, E.Y., Hatje, V., Jeandel, C., Shiller, A.M., Cutter, G.A., Thomas, A., Boyd, P.W., Homoky, W.B., Milne, A., Thomas, H., 
Andersson, P.S., Porcelli, D., Tanaka, T., Geibert, W., Dehairs, F., Garcia-Orellana, J., 2018. Coastal ocean and shelf-sea biogeochemical cycling of trace elements and isotopes: lessons learned from GEOTRACES. Phil. Trans. R. Soc. A 374, 20160076. https://doi.org/10.1098/rsta.2016.0076.

Cornuault, M., Tachikawa, K., Vidal, L., Guihou, A., Siani, G., Deschamps, P., Bassinot, F., Revel, M., 2018. Circulation Changes in the Eastern Mediterranean Sea Over the Past 23,000 Years Inferred From Authigenic Nd Isotopic Ratios. Paleoceanogr. Paleoclimatol. 33, 264-280.

Crocket, K.C., Hill, E., Abell, R.E., Johnson, C., Gary, S.F., Brand, T., Hathorne, E.C., 2018. Rare Earth Element Distribution in the NE Atlantic: Evidence for Benthic Sources, Longevity of the Seawater Signal, and Biogeochemical Cycling. Front. Mar. Sci. 5, 147. https://doi.org/10.3389/fmars.2018.00147.

de Baar, H.J.W., Bacon, M.P., Brewer, P.G., Bruland, K.W., 1985. Rare earth elements in the Pacific and Atlantic Oceans. Geochim. Cosmochim. Acta 49, 1943-1959. https:// doi.org/10.1016/0016-7037(85)90089-4.

de Baar, H.J.W., Bruland, K.W., Schijf., J., van Heuven, S.M.A.C. and Behrens, M.K., 2018. Low cerium among the dissolved rare earth elements in the central North Pacific Ocean. Geochimica et Cosmochimica Acta 236, 5-40

de Walle, F.B., Nikolopoulou-Tamvakli, M. and Heinen, W.J. (eds.), 1993. Environmental Condition of the Mediterranean Sea: European Community Countries. Kluwer Academic Publishers. 525 pp. ISBN: 0-7923-2468-4.

Dubois-Dauphin, Q., Montagna, P., Siani, G., Douville, E., Wienberg, C., Hebbeln, D., Liu, Z., Kallel, N., Dapoigny, A., Revel, M., Pons-Branchu, E., Taviani, M., Colin, C., 2017. Hydrological variations of the intermediate water masses of the western Mediterranean Sea during the past 20 ka inferred from neodymium isotopic composition in foraminifera and cold-water corals. Clim. Past 13, 17-37.

Elderfield, H., 1988. The oceanic chemistry of the rare-earth elements. Philos. Trans. R. Soc. Math. Phys. Eng. Sci. 325, 105-126. https://doi.org/10.1098/rsta.1988.0046.

Falco, P., Trani, M., Zambianchi, E., 2016. Water mass structure and deep mixing processes in the Tyrrhenian Sea: Results from the VECTOR project. Deep-Sea Research I $113,7-21$.

Flecha, S., Pérez, F.F., Murata, A., Makaoui, A., Huertas, I.E., 2019. Decadal acidification in Atlantic and Mediterranean water masses exchanging at the Strait of Gibraltar. Sci. Rep. 9, 15533.

Fowler, S.W., Hamilton, T.F., Peinert, R.D., La Rosa, J., Teyssie, J.-L., 1992. The vertical flux of rare earth elements in the northwestern Mediterranean. Water Pollution Research Report 28, 401-412.

Frank, M., 2002. Radiogenic isotopes: tracers of past ocean circulation and erosional input. Rev. Geophys. 40, 1. https://doi.org/10.1029/2000RG000094.

Frants, M., Gille, S.t., Hewes, C.D., Holm-Hansena, O., Kahru, M., Lombrozo, A., Measures, C.I., Mitchell, G., Wang, H. and Zhou, M., 2013. Optimal multiparameter analysis of source water distributions in the Southern Drake Passage. Deep-Sea Research II 90, 31-42.

Freslon, N., Bayon, G., Toucanne, S., Bermell, S., Bollinger, C., Cheron, S., Etoubleau, J., Germain, Y., Khripounoff, A., Ponzevera, E., Rouget, M.-L., 2014. Rare earth elements and neodymium isotopes in sedimentary organic matter. Geochim. Cosmochim. Acta $140,177-198$.

Fuda, J.L., Etiope, G., Millot, C., Favali, P., Calcara, M., Smriglio, G., Boschi, E., 2002 Warming, salting and origin of the Tyrrhenian Deep Water. Geophys. Res. Lett. 29, $1886-1889$.

Garcia-Solsona, E., Jeandel, C., 2020. Balancing Rare Earth Element distributions in the Northwestern Mediterranean Sea. Chem. Geol. 532, 119372.

Garcia-Solsona, E., Jeandel, C., Labatut, M., Lacan, F., Vance, D., Chavagnac, V., Pradoux, C., 2014. Rare earth elements and Nd isotopes tracing water mass mixing and particle-seawater interactions in the SE Atlantic. Geochim. Cosmochim. Acta 125, 351-372.

Greaves, M.J., Rudnicki, M., Elderfield, H., 1991. Rare earth elements in the Mediterranean Sea and mixing in the Mediterranean outflow. Earth Planet. Sci. Lett. 103 (1-4), 169-181.

Grenier, M., Garcia-Solsona, E., Lemaitre, N., Trull, T.W., Bouvier, V., Nonnotte, P., van Beek, P., Souhaut, M., Lacan, F., Jeandel, C., 2018. Differentiating Lithogenic Supplies, Water Mass Transport, and Biological Processes On and Off the Kerguelen Plateau Using Rare Earth Element Concentrations and Neodymium Isotopic Compositions. Front. Mar. Sci. 5, 426. https://doi.org/10.3389/fmars.2018.00426.

Glover, D.M., Jenkins, W.J., Doney, S.C., 2011. Principal component and factor analysis' in 'Modeling Methods for Marine Science. Cambridge University Press 75-119.

Goldstein, S.L. and Hemming S.R., 2003. Long lived isotopic tracers in oceanography, paleoceanography, and ice sheet dynamics. In Treatise on Geochemistry (ed. H. Elderfield). Elsevier, Ch 6.17.

Guerzoni, S., Molinaroli, E., Chester, R., 1997. Saharan dust inputs to the western Mediterranean Sea: depositional patterns, geochemistry and sedimentological implications. Deep-Sea Res. II 44 (3-4), 631-654.

Haley, B.A., Frank, M., Hathorne, E., Pisias, N., 2014. Biogeochemical implications from dissolved rare earth element and Nd isotope distributions in the Gulf of Alaska. Geochim. Cosmochim. Acta 126, 455-474.

Hathorne, E.C., Stichel, T., Brück, B., Frank, M., 2015. Rare earth element distribution in the Atlantic sector of the Southern Ocean: the balance between particle scavenging and vertical supply. Mar. Chem. 177, 157-171.

Henry, F., Jeandel, C., Dupré, B., Minster, J.-F., 1994. Particulate and dissolved Nd in the western Mediterranean Sea: sources, fate and Budget. Mar. Chem. 45, 283-305.

Iacono, R., Napolitano, E., Marullo, S., Artale, V., Vetrano, A., 2013. Seasonal Variability of the Tyrrhenian Sea Surface Geostrophic Circulation as Assessed by Altimeter Data. J. Phys. Oceanogr. 43, 1710-1732.

Iudicone, D., Buongiorno Nardelli, B., Santoleri, R., Marullo, S., 2003. Distribution and mixing of intermediate water masses in the Channel of Sicily (Mediterranean Sea). J. Geophys. Res. 108 (C9), 8105. https://doi.org/10.1029/2002JC001647, 2003.
Jacobsen, S.B., Wasserburg, G.J., 1980. Sm-Nd isotopic evolution of chondrites. Earth Planet. Sci. Lett. 50, 139-155.

Jeandel, C., 2016. Overview of the mechanisms that could explain the 'Boundary Exchange' at the land-ocean contact. Phil. Trans. R. Soc. A 374, 20150287.

Jeandel, C., Oelkers, E., 2015. The influence of terrigeneous particulate material dissolution on ocean chemistry and global element cycles. Chem. Geol. 395, 50-66.

Jeandel, C., Peucker-Ehrenbrink, B., Jones, M.T., Pearce, C.R., Oelkers, E.H., Godderis, Y., Lacan, F., Aumont, O., Arsouze, T., 2011. Ocean Margins: The Missing Term in Oceanic Element Budgets? Eos 92 (26), 217-224.

Jeandel, C., Delattre, H., Grenier, M., Pradoux, C., Lacan, F., 2013. Rare earth element concentrations and Nd isotopes in the Southeast Pacific Ocean. Geochem. Geophys. Geosyst. 14 (2), 328-341.

Jenkins, W.J., Smethie Jr, W.M., Boyle, E.A., Cutter, G.A., 2015. Water mass analysis for the U.S. GEOTRACES (GA03) North Atlantic sections. Deep-Sea Res. II 116, 6-20.

Jiménez-Espejo, F.J., Pardos-Gené, M., Martínez-Ruiz, F., García-Alix, A., van de Flierdt, T., Toyofuku, T., Bahr, A., Kreissig, K., 2015. Geochemical evidence for intermediate water circulation in the westernmost Mediterranean over the last $20 \mathrm{kyr}$ BP and its impact on the Mediterranean Outflow. Global Planet. Change 135, 38-46.

Johannesson, K.H., Chevis, D.A., Burdige, D.J., Cable, J.E., Martin, J.B., Roy, M., 2011. Submarine groundwater discharge is an important net source of light and middle REEs to coastal waters of the Indian River Lagoon, Florida, USA. Geochim. Cosmochim. Acta 75, 825-843.

Lacan, F., Jeandel, C., 2001. Tracing Papua New Guinea imprint on the central Equatorial Pacific Ocean using neodymium isotopic compositions and rare earth element patterns. Earth Planet. Sci. Lett. 186, 497-512.

Lambelet, M., van de Flierdt, T., Crocket, K., Rehkämper, M., Kreissig, K., Coles, B., Rijkenberg, M.J.A., Gerringa, L.J.A., de Baar, H.J.W., Steinfeldt, R., 2016. Neodymium isotopic composition and concentration in the western North Atlantic Ocean: Results from the GEOTRACES GA02 section. Geochim. Cosmochim. Acta 177, $1-29$.

Lascaratos, A., Roether, W., Nittis, K., Klein, B., 1999. Recent changes in deep water formation and spreading in the eastern Mediterranean Sea: a review. Prog. Oceanogr. 44, 5-36.

Martin, E.E., MacLeod, K.G., Jiménez Berrocoso, A., Bourbon, E., 2012. Water mass circulation on Demerara Rise during the late Cretaceous based on Nd isotopes. Earth Planet. Sci. Lett. 327-328, 111-120.

Millot, C., 1985. Some features of the Algerian Current. J. Geo-phys. Res. 90 (C4), 7169-7176.

Millot, C., 1999. Circulation in the Western Mediterranean Sea. J. Mar. Syst. 20, 423-442.

Millot, C., 2009. Another description of the Mediterranean Sea outflow. Prog. Oceanogr. $82,101-124$.

Millot, C., Taupier-Letage, I., 2005. Additional evidence of LIW entrainment across the Algerian subbasin by mesoscale eddies and not by a permanent westward flow. Prog. Oceanogr. 66, 231-250.

Osborne, A.H., Vance, D., Rohling, E.J., Barton, N., Rogerson, M., Fello, N., 2008. A humid corridor across the Sahara for the migration of early modern humans out of Africa 120,000 years ago. Proc. Natl. Acad. Sci. 105, 16444-16447.

Osborne, A.H., Marino, G., Vance, D., Rohling, E.J., 2010. Eastern Mediterranean surface water Nd during Eemian sapropel S5: monitoring northerly (mid-latitude) versus southerly (sub-tropical) freshwater contributions. Quat. Sci. Rev. 29, 2473-2483.

Pin, C., Zalduegui, J.F.S., 1997. Sequential separation of light rare-earth elements, thorium and uranium by miniaturized extraction chromatography: application to isotopic analyses of silicate rocks. Anal. Chim. Acta 339, 79-89.

Piotrowski, A.M., Galy, A., Nicholl, J.A.L., Roberts, N., Wilson, D.J., Clegg, J.A., Yu, J., 2012. Reconstructing deglacial North and South Atlantic deep water sourcing using foraminiferal Nd isotopes. Earth Planet. Sci. Lett. 357-358, 289-297.

Poole, R., Tomczak, M., 1999. Optimum multiparameter analysis of the water mass structure in the Atlantic Ocean thermocline. Deep-Sea Research I 46, 1895-1921.

Rhein, M., Hinrichsen, H., 1993. Modification of Mediterranean Water in the Gulf of Cadiz, studied with hydrographic, nutrient and chlorofluoromethane data. Deep-Sea Res. Part I 40 (2), 267-291.

Rhein, M., Send, U., Klein, B., Krahmann, G., 1999. Interbasin deep water exchange in the western Mediterranean. J. Geophys. Res. 104, 23495-23508.

Rickli, J., Frank, M., Halliday, A.N., 2009. The hafnium-neodymium isotopic composition of Atlantic seawater. Earth Planet. Sci. Lett. 280, 118-127.

Robinson, A.R., Leslie, W.G., Theocharis, A., Lascaratos, A., 2001. Mediterranean Sea circulation. in Encyclopedia of Ocean Sciences 3, 1689-1705. Elsevier, New York.

Schijf, J., Christenson, E.A., Byrne, R.H., 2015. YREE scavenging in seawater: A new look at an old model. Mar. Chem. 177, 460-471.

Scrivner, A.E., Vance, D., Rohling, E.J., 2004. New neodymium isotope data quantify Nile involvement in Mediterranean anoxic episodes. Geology 32, 565-568.

Serravall, R., Cristofalo, G.C., 1999. On the presence of a coastal current of Levantine intermediate wáter in the central Tyrrhenian Sea. Oceanol. Acta 22 (3), 281-290.

Shabani, M.B., Akagi, T., Masuda, A., 1992. Preconcentration of trace rare-earth elements in seawater by complexation with bis(2-ethylhexyl) hydrogen phosphate and 2ethylhexyl dihydrogen phosphate adsorbed on a C18 cartridge and determination by inductively coupled plasma mass spectrometry. Anal. Chem. 64, 737-743.

Sholkovitz, E.R., Landing, W.M., Lewis, B.L., 1994. Ocean particle chemistry: The fractionation of rare earth elements between suspended particles and seawater. Geochim. Cosmochim. Acta 58 (6), 1567-1579.

Sorgente, R., Drago, A.F., Ribotti, A., 2003. Seasonal variability in the Central Mediterranean Sea circulation. Ann. Geophys. 21, 299-322.

Sparnocchia, S., Gasparini, G.P., Astraldi, M., Borghini, M., Pistek, P., 1999. Dynamics and mixing of the Eastern Mediterranean outflow in the Tyrrhenian basin. J. Mar Syst. 20, 301-317.

Spivack, A.J., Wasserburg, G.J., 1988. Neodymium isotopic composition of the 
Mediterranean outflow and the eastern North Atlantic. Geochim. Cosmochim. Acta $52,2762-2773$.

Stichel, T., Frank, M., Rickli, J., Haley, B.A., 2012. The hafnium and neodymium isotope composition of seawater in the Atlantic sector of the Southern Ocean. Earth Planet. Sci. Lett. 317-318, 282-294.

Tachikawa, K., Athias, V., Jeandel, C., 2003. Neodymium budget in the modern ocean and paleo-oceanographic implications. J. Geophys. Res. 108, 3254. https://doi.org/10. 1029/1999JC000285.

Tachikawa, K., Roy-Barman, R., Michard, A., Thouron, D., Yeghicheyan, D., Jeandel, C., 2004. Neodymium isotopes in the Mediterranean Sea: Comparison between seawater and sediment signals. Geochim. Cosmochim. Acta 68 (14), 3095-3106.

Tanaka, T., Togashi, S., Kamioka, H., Amakawa, H., Kagami, H., Hamamoto, T., Yuhara, M., Orihashi, Y., Yoneda, S., Shimizu, H., Kunimaru, T., Takahashi, K., Yanagi, T., Nakano, T., Fujimaki, H., Shinjo, R., Asahara, Y., Tanimizu, M., Dragusanu, C., 2000. JNdi-1: a neodymium isotopic reference in consistency with LaJolla neodymium. Chem. Geol. 168, 279-281.

Taylor, S.R., McLennan, S.M., 1985. The Continental Crust: Its Composition and Evolution. Blackwell, Oxford, pp. 312.

van de Flierdt, T., Pahnke, K., and GEOTRACES intercalibration participants: Amakawa, H.,Andersson, P., Basak, C., Coles, B., Colin, C., Crocket, K., Frank, M., Frank, N., Goldstein, S.L., Goswami, V., Haley, B.A., Hathorne, E.C., Hemming, S.R., Henderson, G.M., Jeandel, C. Jones, K., Kreissig, K., Lacan, F., Lambelet, M., Martin, E.E., Newkirk, D.R., Obata, H., Pena, L., Piotrowski, A.M., Pradoux, C., Scher, H.D.,
Schöberg, H., Singh, S.K., Stichel, T., Tazoe, H., Vance, D., and Yang, J., 2012. GEOTRACES intercalibration of neodymium isotopes and rare earth element concentrations in seawater and suspended particles. Part 1: reproducibility of results for the international intercomparison. Limnol. Oceanogr.: Methods 10, 234-251.

van de Flierdt, T., Griffiths, A.M., Lambelet, M., Little, S.H., Stichel, T., Wilson, D.J.,

2016. Neodymium in the oceans: aglobal database, a regional comparison and implications for palaeoceanographic research. Phil. Trans. R. Soc. A 374, 20150293.

Vance, D., Scrivner, A.E., Beney, P., Staubwasser, M., Henderson, G.M., Slowey, N.C., 2004. The use of foraminifera as a record of the past neodymium isotope composition of seawater. Paleoceanography 19, PA2009.

Vetrano, A., Napolitano, E., Iacono, R., Schroeder, K., Gasparini, G.P., 2010. Tyrrhenian Sea circulation and water mass fluxes in spring 2004: Observations and model results. J. Geophys. Res. 115, C06023.

Wombacher, F., Rehkämper, M., 2003. Investigation of the mass discrimination of multiple collector ICP-MS using neodymium isotopes and the generalised power law. J. Anal. At. Spectrom. 18, 1371-1375.

Zhang, J., Nozaki, Y., 1996. Rare earth elements and yttrium in seawater: ICP-MS determinations in the East Caroline, Coral Sea, and South Fiji basins of the western South Pacific Ocean. Geochim. Cosmochim. Acta 60 (23), 4631-4644.

Zheng, X.-Y., Plancherel, Y., Saito, M.A., Scott, P.M., Henderson, G.M., 2016. Rare earth elements (REEs) in the tropical South Atlantic and quantitative deconvolution of their non-conservative behavior. Geochim. Cosmochim. Acta 177, 217-237. 